\title{
Review \\ Novel ADCs and Strategies to Overcome Resistance to Anti-HER2 ADCs
}

\author{
Elena Díaz-Rodríguez ${ }^{1,2,+}$, Lucía Gandullo-Sánchez ${ }^{1,+} \mathbb{D}$, Alberto Ocaña $^{3} \mathbb{D}$ and Atanasio Pandiella ${ }^{1, *}$ \\ 1 Instituto de Biología Molecular y Celular del Cáncer, CSIC-IBSAL and CIBERONC, 37007 Salamanca, Spain; \\ ediaz@usal.es (E.D.-R.); lgandullo@usal.es (L.G.-S.) \\ 2 Departamento de Bioquímica y Biología Molecular, University of Salamanca, 37007 Salamanca, Spain \\ 3 Hospital Clínico San Carlos, Centro de Investigación Biomédica en Red de Oncología (CIBERONC), \\ 28040 Madrid, Spain; alberto.ocana@salud.madrid.org \\ * Correspondence: atanasio@usal.es; Tel.: +34-923-294-815 \\ + These authors contributed equally to this work.
}

check for updates

Citation: Díaz-Rodríguez, E.; Gandullo-Sánchez, L.; Ocaña, A.; Pandiella, A. Novel ADCs and Strategies to Overcome Resistance to Anti-HER2 ADCs. Cancers 2022, 14, 154. https://doi.org/10.3390/ cancers14010154

Academic Editor: Jonas Cicenas

Received: 10 December 2021

Accepted: 27 December 2021

Published: 29 December 2021

Publisher's Note: MDPI stays neutral with regard to jurisdictional claims in published maps and institutional affiliations.

Copyright: (C) 2021 by the authors. Licensee MDPI, Basel, Switzerland. This article is an open access article distributed under the terms and conditions of the Creative Commons Attribution (CC BY) license (https:// creativecommons.org/licenses/by/ $4.0 /)$.
Simple Summary: A proportion of breast tumors bear the oncogenic transmembrane tyrosine kinase protein HER2. Even though therapies that target HER2 have changed the prognosis and quality of life of patients with HER2+ breast tumors, resistance to those therapies is still an important clinical problem. To improve the management of those tumors, a new category of antitumor agents, antibodydrug conjugates (ADCs), has emerged. These agents are created by linking a potent cytotoxic to an antibody that recognizes a membrane protein. Two anti-HER2 ADCs have been approved by the FDA for clinical use and several others are under development. The structure, mechanism of action, and resistance mechanisms to ADCs are reviewed in the present work, as well as potential strategies to overcome resistance to clinically approved anti-HER2 ADCs, including novel anti-HER2 ADCs.

\begin{abstract}
During recent years, a number of new compounds against HER2 have reached clinics, improving the prognosis and quality of life of HER2-positive breast cancer patients. Nonetheless, resistance to standard-of-care drugs has motivated the development of novel agents, such as new antibody-drug conjugates (ADCs). The latter are a group of drugs that benefit from the potency of cytotoxic agents whose action is specifically guided to the tumor by the target-specific antibody. Two anti-HER2 ADCs have reached the clinic: trastuzumab-emtansine and, more recently, trastuzumabderuxtecan. In addition, several other HER2-targeted ADCs are in preclinical or clinical development, some of them with promising signs of activity. In the present review, the structure, mechanism of action, and potential resistance to all these ADCs will be described. Specific attention will be given to discussing novel strategies to circumvent resistance to ADCs.
\end{abstract}

Keywords: HER2; ADC; drug resistance

\section{Introduction}

HER2 belongs to the ErbB/HER family of transmembrane tyrosine kinases, which also includes EGFR, HER3, and HER4 [1,2]. Increased activity of HER2 has been linked to the initiation and progression of different tumors [3]. In fact, elevated levels of HER2 were initially identified in a subset of breast tumors, and such overexpression correlated with poor prognosis [4]. That fact prompted the development of targeted therapies specifically designed to act on HER2 [2]. One of these successful therapies relies on the use of antibodydrug conjugates (ADCs) [5,6]. In this review, we will discuss currently approved anti-HER2 $\mathrm{ADCs}$ and strategies to overcome resistance against them.

\section{ADCs' General Structure}

ADCs are sophisticated versions of antibodies that target cell surface proteins $[7,8]$. They consist of three components: (i) an antibody directed to a cell surface protein; (ii) a 
cytotoxic agent (also known as payload or warhead); and (iii) a linker used to attach the cytotoxic to the antibody (Figure 1).

\begin{tabular}{|c|c|c|c|}
\hline \multicolumn{4}{|c|}{ ANTIBODY } \\
\hline $\begin{array}{c}\text { Biparatopic } \\
\text { anti-HER2 } \\
Z W 49 \\
M E D / 4276\end{array}$ & $\begin{array}{c}\text { IgG anti HER2 } \\
R C 48-A D C \\
M R G 002 \\
\text { PF06804103 } \\
\text { SBT6050 } \\
\text { BAT8001 } \\
\text { DHES0815A }\end{array}$ & $\begin{array}{c}\text { Trastuzumab } \\
T-D M 1 \\
T-D X d \\
\text { SYD985 } \\
\text { A166 } \\
\text { FS-1502 } \\
\text { GQ1001 }\end{array}$ & $\begin{array}{c}\text { Trastuzumab } \\
\text { variants and } \\
\text { biosimilars } \\
A R X 788 \\
A L T-P 7 \\
B D C 1001\end{array}$ \\
\hline
\end{tabular}

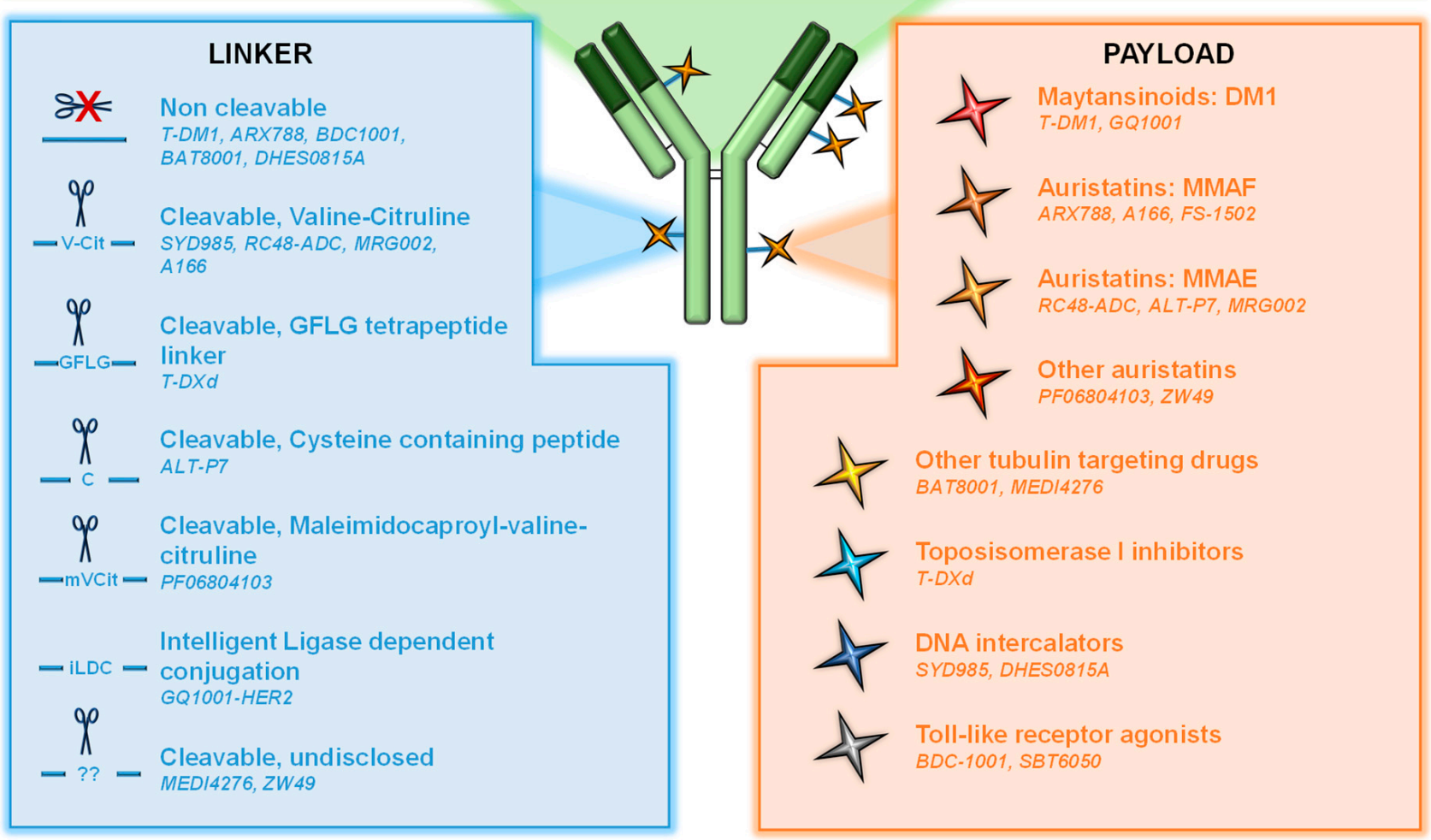

Figure 1. Schematic representation of an ADC. The three basic components of an ADC are shown: antibody, payload, and linker. In addition, different alternatives of those components in anti-HER2 ADCs are illustrated.

At the time of writing this review, twelve ADCs have been approved by the FDA and several hundred are now being investigated in clinical or preclinical settings. In the case of the anti-HER2 ADCs, most of them use, as an antibody, the trastuzumab backbone or a modified version of this antibody (e.g., ARX788).

Cytotoxic agents used as payloads in ADCs can be divided into two groups: antimicrotubule compounds (maytansinoids or auristatins) and DNA-damaging agents (topoisomerase inhibitors or DNA intercalators). Maytansinoids as mertansine (DM1) or DM4 are synthetic derivatives of maytansine, an inhibitor of microtubule polymerization. They bind to tubulin, leading to mitotic arrest and cell death $[9,10]$ (Figure 2). DM1 is the warhead of trastuzumab-emtansine (T-DM1), the first ADC approved for the treatment of solid tumors [11]. Auristatins such as monomethyl auristatin E (MMAE) and F (MMAF) are synthetic compounds derived from the natural antimitotic drug dolastatin 10, isolated from the marine sea hare Dolabella auricularia [12,13]. 


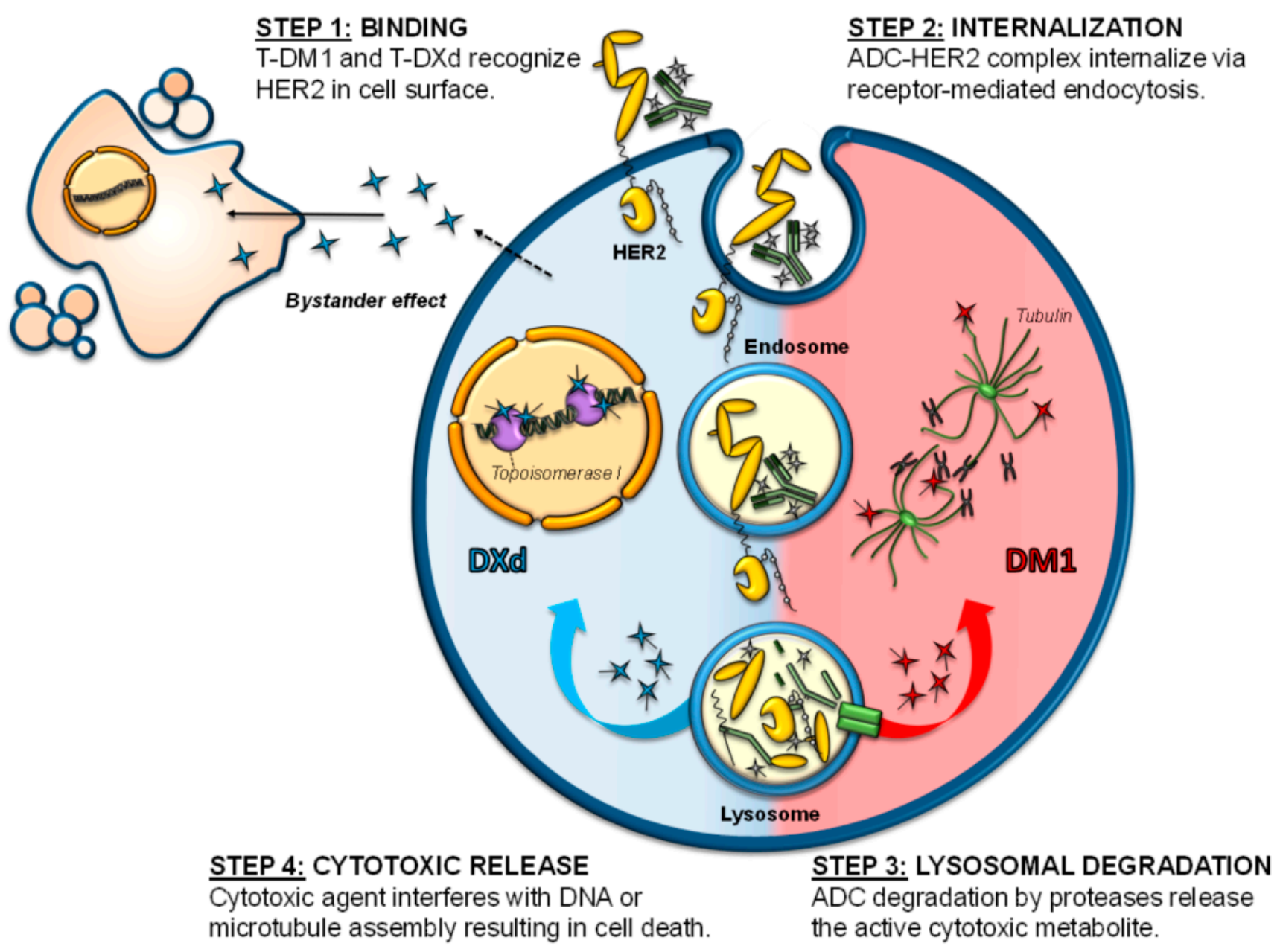

Figure 2. Mechanism of action of anti-HER2 ADCs. The figure schematizes the different steps involved in the action of anti-HER2 ADCs, which include: (step 1) binding of the ADC to HER2, (step 2) internalization of the ADC-HER2 complex, (step 3) lysosomal degradation of the ADC, and (step 4) release of the payloads to the cytosolic compartment. DM1 inhibits microtubule polymerization by targeting tubulin, while DXd moves to the nucleus causing DNA damage by targeting topoisomerase I.

Topoisomerase I inhibitors include deruxtecan (DXd), the warhead used in the recently approved anti-HER2 ADC trastuzumab-deruxtecan. DXd is a highly potent derivative of exatecan, a water-soluble structural analog of camptothecin with unique hexacyclic structure [14,15]. These agents bind and stabilize the topoisomerase I-DNA complex, inhibiting the religation of DNA breaks and thereby hampering DNA replication and triggering apoptotic cell death (Figure 2). DNA intercalators act on the minor groove of the DNA, inducing double-strand breaks and subsequent cell apoptosis [16]. An example of these payloads is duocarmycin, which has been incorporated, for example, in the development of trastuzumab-duocarmycin or SYD985. In this case, as duocarmycin is rapidly degraded in plasma, it is incorporated into the ADC in its inactive pro-drug form, seco-duocarmycin-hydroxybenzamide-azaindole (seco-DUBA). Once released into the cells, duocarmycin binds the minor groove of the DNA in an AT-rich region, causing DNA alkylation and DNA damage in both dividing and non-dividing cells $[16,17]$.

An important aspect to be considered in the generation of ADCs is the amount of cytotoxic moiety loaded on the antibody, also known as DAR (Drug to Antibody Ratio). In fact, different DARs have been used for the development of different ADCs, with the most typical DAR being between 2 to $8[7,18]$ (Table 1 ). 
Table 1. Anti-HER2 ADCs approved for use or in clinical development (in clinical trials).

\begin{tabular}{|c|c|c|c|c|c|c|}
\hline ADC & Antibody & Payload & Linker & DAR & Status & $\begin{array}{l}\text { Clinical Trials and } \\
\text { References }\end{array}$ \\
\hline T-DM1 & Trastuzumab & DM1 & Non-cleavable & 3.5 & Approved & \\
\hline T-DXd & Trastuzumab & Deruxtecan & Cleavable & $6-8$ & Approved & \\
\hline SYD985 & Trastuzumab & $\begin{array}{l}\text { Duocarmycin } \\
\text { (seco-DUBA) }\end{array}$ & $\begin{array}{c}\text { Cleavable } \\
\text { (valine-citruline) }\end{array}$ & 2.8 & & $\begin{array}{c}\text { NCT03262935, phase III } \\
\text { NCT04602117, phase I/Ib } \\
\text { NCT02277717, phase I } \\
\text { NCT04205630, phase II } \\
\text { NCT04235101, phase I }\end{array}$ \\
\hline ARX788 & $\begin{array}{l}\text { Modified } \\
\text { trastuzumab }\end{array}$ & MMAF & $\begin{array}{l}\text { Non-cleavable } \\
\text { (Amberstatin, } \\
\text { AS269) }\end{array}$ & 1.9 & $\mathrm{CT}$ & $\begin{array}{l}\text { NCT05018676, phase II } \\
\text { NCT05018702, phase II } \\
\text { NCT048299604, phase II } \\
\text { NCT04983121, phase II } \\
\text { NCT05041972, phase II } \\
\text { NCT03255070, phase I } \\
\text { NCT02512237, phase I }\end{array}$ \\
\hline RC48-ADC & Ig anti-Her2 & MMAE & $\begin{array}{c}\text { Cleavable } \\
\text { (valine-citruline) }\end{array}$ & 4 & $\mathrm{CT}$ & $\begin{array}{l}\text { NCT03052634, phase I/II } \\
\text { NCT04400695, phase III } \\
\text { NCT03500380, phase II/III } \\
\text { NCT04311034, phase I/II } \\
\text { NCT04714190, phase III } \\
\text { NCT03556345, phase II } \\
\text { NTC05016973, phase II } \\
\text { NCT04879329, phase II } \\
\text { NCT04264936, phase I/II } \\
\text { NCT03809013, phase II } \\
\text { NCT03507166, phase II } \\
\text { NCT04073602, phase II } \\
\text { NCT04965519, phase II } \\
\text { NCT04329429, phase II } \\
\text { NCT04280341, phase I } \\
\text { NCT02881138, phase I } \\
\text { NCT02881190, phase I }\end{array}$ \\
\hline ALT-P7 & $\begin{array}{c}\text { Trastuzumab } \\
\text { variant }\end{array}$ & MMAE & $\begin{array}{c}\text { Cysteine } \\
\text {-containing peptide }\end{array}$ & UD & $\mathrm{CT}$ & NCT03281824, phase I \\
\hline MRG002 & IgG anti-HER2 & MMAE & $\begin{array}{c}\text { Cleavable } \\
\text { (valine-citruline) }\end{array}$ & 3.8 & $\mathrm{CT}$ & $\begin{array}{l}\text { CTR20181778, phase I } \\
\text { NCT04924699, phase II } \\
\text { NCT04941339, phase I } \\
\text { NCT04839510, phase II } \\
\text { NCT04837508, phase II } \\
\text { NCT04742153, phase II } \\
\text { NCT04492488, phase I/II }\end{array}$ \\
\hline A166 & Trastuzumab & MMAF & $\begin{array}{c}\text { Cleavable } \\
\text { (valine-citruline) }\end{array}$ & UD & $\mathrm{CT}$ & NCT03602079, phase I/II \\
\hline PF06804103 & IgG1 antiHER2 & $\begin{array}{l}\text { Auristatin } \\
0101\end{array}$ & $\begin{array}{c}\text { Cleavable } \\
\text { (Maleimidocaproyl- } \\
\text { valine-citruline) }\end{array}$ & 4 & $\mathrm{CT}$ & NCT03284723, phase I \\
\hline MEDI4276 & Trastuzumab scFV & MMETA & Protease cleavable & 4 & $\mathrm{CT}$ & NCT02576548, phase I/II \\
\hline BDC1001 & $\begin{array}{c}\text { Trastuzumab } \\
\text { biosimilar }\end{array}$ & $\begin{array}{l}\text { TLR } 7 / 8 \\
\text { agonist }\end{array}$ & Non-cleavable & UD & $\mathrm{CT}$ & NCT04278144, phase I/II \\
\hline SBT6050 & IgG anti-HER2 & TLR8 agonist & & & $\mathrm{CT}$ & $\begin{array}{l}\text { NCT05091528, phase I/II } \\
\text { NCT04460456, phase I }\end{array}$ \\
\hline FS-1502 & Trastuzumab & MMAF & Beta-glucuronide & 2 & $\mathrm{CT}$ & NCT03944499, phase I \\
\hline
\end{tabular}


Table 1. Cont.

\begin{tabular}{|c|c|c|c|c|c|c|}
\hline ADC & Antibody & Payload & Linker & DAR & Status & $\begin{array}{c}\text { Clinical Trials and } \\
\text { References }\end{array}$ \\
\hline ZW49 & $\begin{array}{c}\text { Biparatopic } \\
\text { antiHER2 IgG }\end{array}$ & Auristatin & Cleavable & UD & $\mathrm{CT}$ & NCT03821233, phase I \\
\hline BAT8001 & IgG1 antiHER2 & Batansine & Non-cleavable & UD & $\mathrm{CT}$ & $\begin{array}{l}\text { NCT04189211, phase I } \\
\text { NCT04151329, phase I/II } \\
\text { NCT04185649, phase III }\end{array}$ \\
\hline DHES0815A & IgG antiHER2 & PBD-MA & Non-cleavable & 2 & $\mathrm{CT}$ & NCT03451162, phase I \\
\hline GQ1001 & Trastuzumab & DM1 & $\begin{array}{c}\text { UD Intelligent } \\
\text { ligase dependent } \\
\text { conjugation }\end{array}$ & UD & $\mathrm{CT}$ & NCT04450732, phase I \\
\hline DP303c & IgG antiHER2 & UD & & & $\mathrm{CT}$ & $\begin{array}{l}\text { NCT04146610, phase I } \\
\text { NCT04828616, phase II } \\
\text { NCT04826107, phase II }\end{array}$ \\
\hline BB-1701 & IgG antiHER2 & UD & & & $\mathrm{CT}$ & NCT04257110, phase I \\
\hline SHR-A1811 & IgG antiHER2 & UD & & & $\mathrm{CT}$ & $\begin{array}{c}\text { NCT04446260, phase I } \\
\text { NCT04818333, phase I/II } \\
\text { NCT04513223 phase I }\end{array}$ \\
\hline B003-101 & IgG antiHER2 & UD & & & $\mathrm{CT}$ & NCT03953833, phase I \\
\hline
\end{tabular}

The linkers used to attach the payload to the antibody can be classified into cleavable and non-cleavable (Figure 1) [19,20]. The specific design of the linkers determines many aspects of ADC pharmacology, such as drug stability into circulation, tumor cell permeability, or DAR [21,22]. In non-cleavable linkers, the bond between the cytotoxic and the antibody is resistant to proteolytic degradation. These kinds of linkers exhibit higher stability at the expense of lower membrane permeability. In the case of cleavable linkers, these can be cut in response to environmental factors such as $\mathrm{pH}$ (acid-labile linkers as hydrazine linkers), specific lysosomal proteases as cathepsin B (protease-cleavable linkers), or glutathione reduction (disulfide linkers) [23]. These linkers can facilitate the release of the chemical agent within the microenvironment acting on tumoral cells in proximity that can express or not express the target. This action is called the bystander effect [24].

In addition to the chemical linker, the method leading to that binding is another important issue. Initially, conjugation relied on lysine and interchain cysteines [19], although currently most ADCs rely on interchain disulfide cysteines for conjugation, in which the interchain disulfide bonds are reduced by an excess of reducing agent, disrupting them and freeing sulfhydryl groups, finally resulting in more homogeneous ADCs and DAR numbers [25]. In addition, novel site-specific conjugation methods using unique linker chemistries leading to homogeneous ADCs with desired DARs have emerged [25,26], such as engineering unnatural aminoacids as $p$-acethylphenylalanine or $p$-azidomethyl-Lphenylalanine $[27,28]$.

\section{Mechanism of Action of ADCs}

When ADCs bind to their target at the cell surface, the antigen-ADC complex is internalized via receptor-mediated endocytosis (clathrin- or caveolae- endocytosis) or pinocytosis [29,30] (Figure 2). Internalization results in inward budding of the cell membrane to form an early endosome that will further mature into a late endosome before fusing to lysosomes [31]. The whole antigen-ADC complex is then degraded. In the case of ADCs with cleavable linkers, cleavage can occur in early or late endosomes or even in the lysosomes. Nonetheless, in ADCs with non-cleavable linkers, cleavage happens at the 
lysosomal compartment and requires the action of acidic proteases such as cathepsin B or plasmin [31].

In both cases, and after cleavage, ADC payloads are small molecules that can be transported from the lysosomal lumen to the cytosol, where they are able to induce their action either in that compartment (e.g., antimicrotubular drugs) or after translocation to the nucleus (e.g., DNA damagers). In any case, the final consequence would be the induction of cell death [32]. In some cases, the cytotoxic payload, once liberated in the cytoplasm, may be expelled from the cell or be released in the tumor microenvironment after cell death. In that circumstance, cells that do not express the target antigen may be affected by the cytotoxic payload, inducing what is known as the bystander killing effect [24,33] (Figure 2). This effect depends on several factors, such as the kind of linker or the properties of the payload, but the presence of cell-permeable payloads will increase the effect [34].

\section{ADCs in HER2-Positive Breast Cancer}

\subsection{Approved Anti-HER2 ADCs}

\subsubsection{T-DM1}

Trastuzumab emtansine, ado-trastuzumab emtansine, or T-DM1 (Kadcyla ${ }^{\mathrm{TM}}$ ), was the first ADC approved for the treatment of solid tumors, in February 2013 [11]. It bases its activity on the action of the anti-HER2 monoclonal antibody trastuzumab that is covalently bound through an uncleavable thioether linker to the cytotoxic agent mertansine (emtansine or DM1, Figure 1) [35,36]. In the case of T-DM1, the DAR is 3.5. All the cytotoxic functions of trastuzumab, such as antibody-dependent cell-mediated cytotoxicity (ADCC), cell cycle arrest, or signaling inhibition, are maintained and potentiated by the antitumoral actions of DM1 [36-38]. DM1 catabolites, once released into the cytosol, will inhibit microtubule polymerization in target cells, causing cell cycle arrest in $\mathrm{G}_{2} / \mathrm{M}$ [36], mitotic catastrophe, and cell death (Figure 2) [39,40].

T-DM1 has proved its value and effectiveness in different clinical settings, including early and advanced breast cancer. Thus, more than 100 clinical trials have evaluated or are studying different aspects of T-DM1 biology and function, either alone or in combination, on both primary tumors and metastatic lesions [35]. Approval of this agent in metastatic breast cancer was based in two phase III clinical trials, EMILIA and TH3RESA, that demonstrated significant improvement in progression-free survival (PFS) and overall survival (OS) with a good safety profile. The EMILIA trial compared the action of T-DM1 with that of the anti-HER2 therapy lapatinib, in combination with capecitabine, and after progression to a trastuzumab-based first line therapy [11]. The TH3RESA trial compared T-DM1 with the physician's choice in a heavily pretreated population [41]. More recently, the KATHERINE trial allowed the approval of T-DM1 in the post-neoadjuvant setting for patients with residual invasive breast cancer after neoadjuvant therapy [42]. MARIANNE was the first phase III trial to evaluate the efficacy of T-DM1 in first line treatment. Surprisingly, the addition of pertuzumab, another anti-HER2 antibody approved in the clinic, to T-DM1 did not improve the trastuzumab plus taxane arm in terms of OS, PFS or overall response rate (ORR), although the safety profile and tolerability were much better $[43,44]$. Thus, in summary, T-DM1 is now indicated as a single agent in the adjuvant treatment of patients with HER2-positive (HER2+) early breast cancer who have residual invasive disease after neoadjuvant taxane and trastuzumab-based treatment, and in patients with metastatic breast cancer who previously received trastuzumab and/or a taxane, and either received previous therapy for metastatic disease or developed disease recurrence during or within six months of completing adjuvant therapy.

In general, T-DM1 is associated with manageable (grade 1/2) adverse events, such as gastrointestinal toxicity, neuropathy, left ventricular ejection fraction decline, or, in a minority of cases, high grade toxicities such as thrombocytopenia and increase in liver enzymes $[45,46]$. 


\subsubsection{Trastuzumab Deruxtecan}

In December 2019, the trastuzumab-based ADC trastuzumab-deruxtecan (T-DXd, Enhertu $^{\mathrm{TM}}$ ) reached oncology clinics. T-DXd was initially named DS8201a and has been approved for the management of advanced stage HER2+ breast cancer. As with T-DM1, the antibody backbone is trastuzumab, but in this case combined to the topoisomerase I inhibitor deruxtecan, with a final DAR of 7-8 [47]. A cleavable tetrapeptide linker (Gly-Phe-Leu-Gly, GFLG, Figure 1), potentially degradable by the lysosomal proteases cathepsin B and L, is used. DXd, once released, will bind to the topoisomerase I-DNA complex through hydrogen bonds resulting in a ternary stable complex that will prevent DNA religation, generating single and double-strand breaks and leading to apoptotic cell death (Figure 2) [47]. In addition, the liberated payload will reach high intracellular concentration and is membrane permeable [47], therefore capable of exerting a bystander effect [48]. All of these characteristics give T-DXd high stability in plasma and strong antitumor activity across a wide number of HER2+ tumor types [47], including HER2 low tumors or those with heterogeneous expression of HER2 [48]. The antitumoral action of T-DXd on HER2 low tumors has recently been supported by data from the DAISY trial [49].

T-DXd was approved by the FDA for the treatment of HER2+ advanced breast cancer patients who have received at least two prior lines of anti-HER2 therapies [50]. The multicenter single-arm phase II study DESTINY-Breast01 enrolled 184 patients with HER2+ metastatic breast cancer who had been treated with T-DM1 to define T-DXd pharmacokinetics and doses. The study also included patients who suffered tumor progression to T-DM1 or discontinued T-DM1 due to toxicities. The response rate at a dose of $5.4 \mathrm{mg} / \mathrm{kg}$ was $60.9 \%$ with a confidence interval of 53.4-68.0 and a median duration of the response of 14.8 months [50]. The most common toxicities noted were myelosuppression and nausea, which were associated with interstitial lung disease in $15.2 \%$ of patients in grades $1-2$, but in $2.7 \%$ of patients this toxicity was fatal [51].

Currently, T-DXd is under investigation in over 40 active phase I-III clinical trials registered on ClinicalTrials.gov and comprising different solid organ malignancies, including HER2+ gastric cancer, non-small cell lung cancer, and urothelial or colorectal carcinoma. Its action is also being tested in different breast cancer settings including, among others, residual invasive breast cancer following neoadjuvant therapy (NCT04622319, phase III), alone or in combination with the standard of care in first line therapy (NCT04784715, phase III), in combination with other new anti-HER2 therapies such as tucatinib (NCT04539938, phase II; NCT04538742, phases I/II; and NCT05091528, phases I/II); in HER2 low breast cancer (NCT04494425, phase III; NCT04553770, phase II; NCT03734029, phase III; and NCT04556773, phase I); or in combination with the immunotherapeutic agents nivolumab or pembrolizumab (NCT03523572, phase I and NCT04042701, phase I). In fact, it has been reported that in animal models, T-DXd is able to induce antitumor immunity in combination with anti-CTLA-4 antibodies [52].

Interestingly, T-DXd may also be effective in the context of brain metastases derived from advanced breast cancer. These types of lesions are frequent in advanced settings of the disease and their treatment options are very limited. The DESTINY-Breast01 trial (NCT03248492) demonstrated strong clinical activity of T-DXd, both on HER2+ metastatic breast cancer and brain metastases [53]. This scenario is now being evaluated and validated in several clinical trials (NCT04739761, phase III; NCT04752059, phase II; and NCT04420598, phase II).

\subsection{Other HER2-Directed ADCs in Clinical Development}

\subsubsection{Trastuzumab Duocarmycin-SYD985}

SYD985 is an ADC in which trastuzumab is linked to the potent DNA alkylating agent seco-duocarmycin-hydroxybenzamide-azaindole (seco-DUBA), an alkaloid isolated from Streptomyces [54,55]. Duocarmycins bind to the minor groove of DNA and irreversibly alkylate adenine at the N3 position, disrupting nucleic acid structure and leading to cell death $[56,57]$. SYD985 contains a linker cleavable by proteases at a valine-citrulline 
dipeptide (Figure 1). Interestingly, SYD985 has been shown to be able to overcome resistance to T-DM1 in vitro using both cellular and animal models [58]. SYD985 has been granted fast track designation status by the FDA for metastatic breast cancer [54,59]. Several trials are testing its action on different malignancies and stages, such as advanced or metastatic breast cancer in the TULIP trial (NCT03262935, phase III); HER2 low tumors (NCT04602117, phases I/Ib); the safety, pharmacokinetics, and efficacy on locally advanced or metastatic solid tumors (NCT02277717); recurrent, advanced, or metastatic endometrial carcinoma (NCT04205630, phase II); or in combination with niraparib in patients with solid tumors (NCT04235101, phase I) (Table 1).

\subsubsection{ARX788}

ARX788 is based in a humanized anti-HER2 antibody that is modified with a nonnatural amino acid ( $p$-acetyl-phenylalanine, $p A c F)$. The latter binds, through a non-cleavable amberstatin drug-linker (AS269), to the N-terminus of MMAF [60]. The resulting ADC is highly homogeneous with a DAR of 1.9. Preclinical data indicate that it exhibits elevated serum stability in animal models with a relatively long half-life (12.5 days) [61]. This compound may overcome resistance to other anti-HER2 therapies, such as T-DM1 [61,62]. ARX788 is currently being tested in several phase II clinical trials in advanced metastatic HER2+ breast cancer resistant to other anti-HER2 therapies (NCT05018702, NCT048299604); in combination with the small HER2 tyrosine kinase inhibitor pyrotinib (NCT04983121); in HER2low breast cancer (NCT05018676, phase II); and in other HER2+ tumors (NCT05041972, NCT03255070, and NCT02512237) (Table 1). Based on all the preclinical and clinical data, and similarly to SYD985, ARX788, has been granted a fast-track designation by the FDA (January 2021) in patients with advanced or metastatic breast cancer who have previously received one or more HER2-targeted regimens in the metastatic setting, pending confirmatory studies.

\subsubsection{RC48-ADC}

Disitamab vedotin (RC48-ADC) is an anti-HER2 humanized antibody conjugated to MMAE via the cleavable linker maleimidocaproyl-valyl-citrullinyl- $p$-aminobenzyloxycarbonyl (mc-val-cit-PABC), with a typical DAR of 4 . Several preclinical studies have demonstrated the potent antitumoral action of this conjugate, both in vitro and in vivo [63-65]. In addition, promising results have been obtained in the preclinical setting using animal models, when combining this therapy with immune checkpoint inhibitors [66]. Based on these promising preclinical data, several clinical studies are verifying the beneficial effects of this ADC in different settings $[67,68]$, including phase I/II and phase III trials and in advanced solid tumors, including breast cancer (NCT02881138, phase I; NCT02881190, phase I; NCT03052634, phase I/II; NCT04400695, phase III; and NCT03500380, phases II/III), non-small cell lung cancer (NCT04311034, phases I/II), gastric tumors (NCT04714190, phase III and NCT03556345, phase II), urothelic/bladder tumors (NTC05016973, phase II; NCT04879329, phase II; NCT04264936, phases I/II; NCT03809013, phase II; NCT03507166, phase II; and NCT04073602, phase II), gynecological tumors (NCT04965519, phase II), and biliary tract malignancies (NCT04329429, phase II). It is being tested as monotherapy or combined with other anti-HER2 therapies, conventional chemotherapeutic agents, or immune checkpoint inhibitors (NTC04280341 and NCT04264936). Interestingly, some of these trials are aimed at investigating the effect of this ADC in HER2-low tumors, an entity that so far cannot benefit from the anti-HER2 therapies available to date (NCT04400695).

\subsubsection{ALT-P7}

In this ADC, two molecules of MMAE are site-specifically conjugated to a cysteinecontaining peptide motif of a trastuzumab variant, and its efficacy is being tested in a phase I clinical trial on metastatic breast cancer (NCT03281824) [69]. 


\subsubsection{MRG002}

This ADC also links a humanized anti-HER2 IgG1 to MMAE through a protease cleavable valine-citruline linker, with an average DAR of 3.8. Preclinical studies indicate a favorable toxicity profile and potent antitumor activities in breast and gastric PDX models [70]. Its clinical activity is being investigated in an ongoing phase I study for safety, tolerability, and pharmacokinetics in breast and gastric cancer (CTR20181778) [71]. In addition, several studies are recruiting patients to test this compound in different clinical settings, including gastric, urothelial or biliary tract HER2+ cancer, and HER2 low breast cancer, among others (NCT04924699, NCT04941339, NCT04839510, NCT04837508, NCT04742153, and NCT04492488).

\subsubsection{A166}

This agent uses the MMAF-derivative duostatin- 5 as the warhead. Its action is being tested in a phase I/II clinical trial in monotherapy on several HER2+ solid tumors (NCT03602079) [72].

\subsubsection{PF-06804103}

This ADC is comprised of a humanized IgG1 anti-HER2 antibody site-specifically linked to auristatin 0101 through a protease cleavable linker [73,74]. The action of this compound is now being analyzed in a phase I clinical trial (NCT03284723) [75].

\subsubsection{MEDI 4276}

MEDI4276 is a biparatopic multiepitope ADC that uses the scFV of trastuzumab and the payload MMETA, a derivative of tubulysin also known as AZ13599185, bound through site specific conjugation to two engineered cysteine residues on the heavy chain of the antibody via a maleimidocaproyl protease cleavable linker [76,77]. The characteristics and safety of this preparation are currently being evaluated in a phase I/II trial on HER2 expressing advanced solid tumors (NCT02576548), including breast and gastric cancers. First results from this study point to the clinical efficacy of this agent, but with high toxicities [78].

\subsubsection{BDC-1001}

BDC-1001 is a novel immune-stimulating antibody conjugate consisting of a trastuzumab biosimilar chemically conjugated to a toll-like receptor (TLR) 7/8 agonist to induce immunestimulation at the tumor site. This agent is being tested in advanced HER2+ solid tumors in a phase I/II trial (NCT04278144).

\subsubsection{SBT6050}

Similarly, SBT6050, a therapeutic agent comprised of a potent TLR8 agonist bound to a HER2 IgG, has been developed and its action is being evaluated in HER2+ solid tumors alone or in combination with other anti-HER2 or immune therapies (NCT05091528, NCT04460456).

\subsubsection{FS-1502 (LCB14-0110)}

FS-1502 is a novel prenyl transferase-mediated, site-specific ADC that uses MMAF as the payload, bound to trastuzumab through a beta-glucuronide linker that confers to the final molecule high stability and good pharmacokinetic profile [79]. Its action in vivo is being tested in the phase I clinical trial NCT03944499.

\subsubsection{ZW49}

In ZW49, a biparatopic anti-HER2 IgG is bound to auristatin through a proteasecleavable linker [80]. Its action is being tested on different HER2+ tumors (NCT03821233) [81]. 


\subsubsection{BAT 8001}

This ADC incorporates the maytansinoid payload batansine to a humanized antiHER2 IgG1 through a non-cleavable linker. NCT04189211 and NCT04151329 phase I/II clinical trials are analyzing its action on metastatic breast cancer, with promising results [82]. In addition, a phase III trial has been launched to compare its action to that of lapatinib plus capecitabine (NCT04185649).

\subsubsection{GQ1001}

GQ1001-HER2 is an ADC in which trastuzumab has been linked to the warhead DM1 through an intelligent ligase dependent conjugation (iLDC) system, and whose action is being evaluated in the phase I clinical trial NCT04450732, in the context of advanced solid tumors.

\subsubsection{DHES0815A-RG6148}

DHES0815A-RG6148 consists of an anti-HER2 mAb linked to the DNA minor groove crosslinking agent pyrrolo(2,1-c)(1,4)benzodiazepine monoamide (PDB-MA). Preclinical in vitro and in vivo data have demonstrated high antitumoral activity [83]. The safety, tolerability, and pharmaco-kinetic properties of this ADC are being tested in a phase I trial on HER2+ breast cancer patients for whom established treatments have proven ineffective, intolerable, or unavailable (NCT03451162).

Several other ADCs targeting HER2 but with undisclosed payloads are under different degrees of clinical development (Table 1).

\section{Mechanisms of Resistance}

Several mechanisms of resistance to trastuzumab or T-DM1 have been described (Figure 3). Currently, there are no described mechanisms of resistance to T-DXd, but it is expected that some mechanisms described for trastuzumab and/or T-DM1 can be extrapolated to T-DXd.

\subsection{Alterations in HER2}

T-DM1 and T-DXd are ADCs directed against HER2; therefore, the decrease in the levels of HER2 or structural alterations in this receptor are possible causes of resistance $[84,85]$. In cell lines and in patient samples, dual treatment with trastuzumab and pertuzumab reduces HER2 levels, decreasing the efficacy of T-DM1 as a second-line treatment [86]. A recent study affirms the need to retest HER2 status in metastatic HER2+ breast cancer after treatment, due to the expression changes observed in HER2 [87]. In that study, patients with loss of HER2 showed worse responses to T-DM1 and inferior OS. Other previous studies have also shown discrepancies (both loss and gain) in HER2 expression levels between primary and metastatic breast cancer lesions, with HER2 loss being more frequent, as well as in samples pre- and post-treatment with anti-HER2 therapies [88-92].

In the KRISTINE trial, a subgroup of 15 patients treated with T-DM1 and pertuzumab who had experienced locoregional progression before surgery showed high heterogeneity in HER2 expression, which may have contributed to the worse clinical outcomes observed in T-DM1 treatment [93]. This phenomenon has also been observed in HER2+ gastric cancer, in which it was reported that a large segment of the patients lost their positivity for HER2 status, and their response to T-DM1 decreased [94]. On the other hand, loss of ERBB2 amplification was observed in circulating tumor DNA in patients with primary resistance to T-DM1 [95]. In several cell lines generated in vitro with acquired resistance to T-DM1, a decrease in HER2 expression has been observed compared to parental cells [58,62,96-100].

In addition to loss of HER2, the expression of truncated forms of HER2 can also be responsible for resistance to trastuzumab or T-DM1. For example, p95HER2 generates resistance to trastuzumab by lacking subdomain IV, to which trastuzumab binds [101]. The expression of MUC4, a membrane-associated mucin, is also related to resistance to trastuzumab by partially masking HER2 and preventing its binding [102]. 


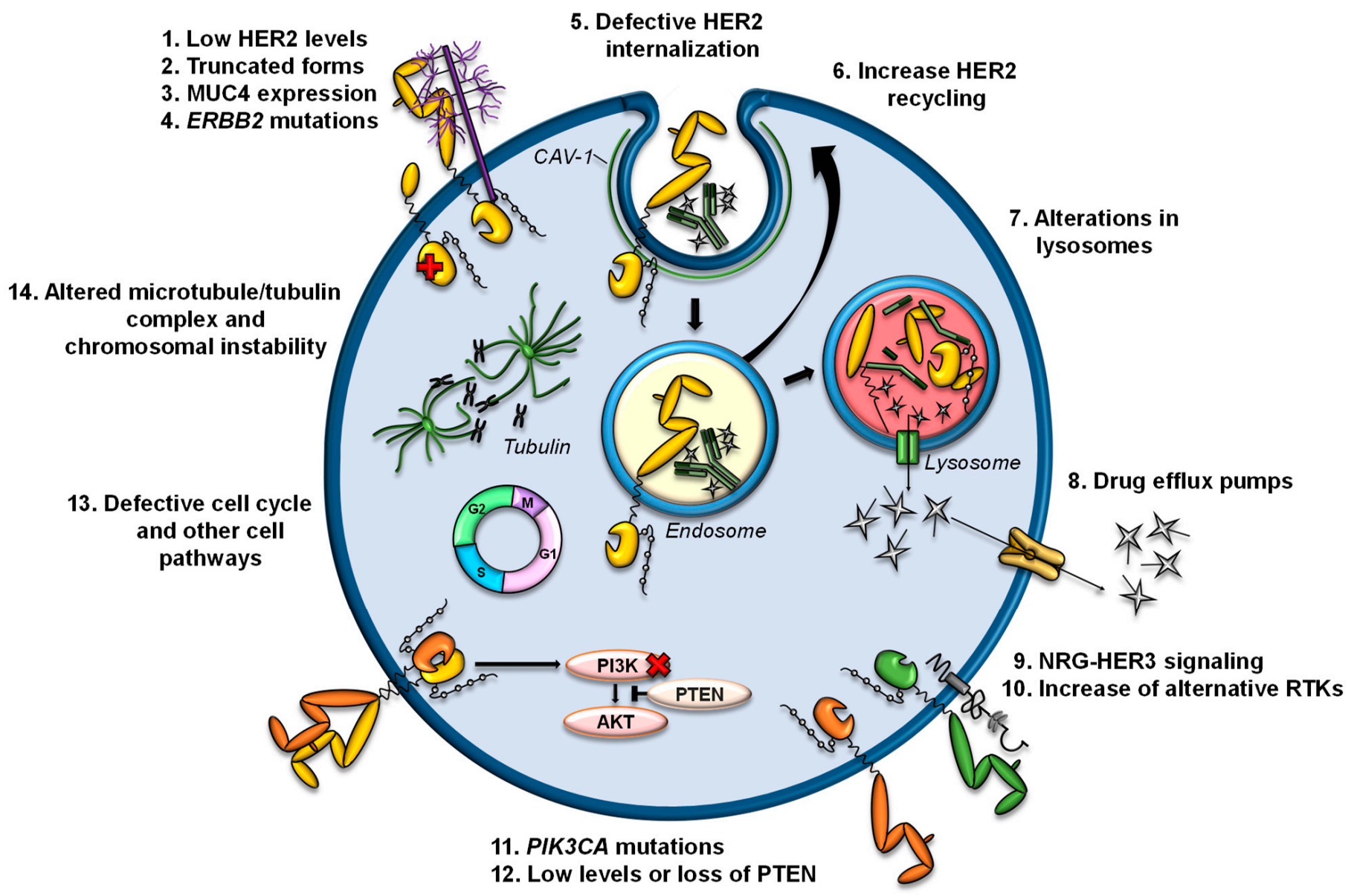

Figure 3. Potential mechanisms of resistance to anti-HER2 ADCs. The mechanisms of resistance to anti-HER2 ADCs are numbered and illustrated. Detailed descriptions are presented in the text.

A splice variant of $E R B B 2$ that removes exon 16 in the extracellular domain of HER2 (d16HER2) has been described in breast cancers and HER2+ cell lines [103,104]. Cell lines expressing d16HER2 were initially resistant to trastuzumab (although the trastuzumab epitope was conserved). It has also been reported recently that the d16HER2 isoform confers resistance to T-DM1 in vitro, due to the low internalization of d16HER2 [105]. However, other studies conducted in vivo, with data and samples from HER2+ breast cancer and gastrointestinal patients, indicate that tumors expressing the d16HER2 isoform are sensitive to trastuzumab [106-109]. Despite these controversies regarding d16HER2, there is no clinical evidence associating d16HER2 with resistance to trastuzumab and/or ADCs targeting HER2 [110].

On the other hand, intracellular mutations in ERBB2, mainly in the kinase domain, which have been associated with resistance to trastuzumab $[111,112]$, could also result in resistance to T-DM1 and T-DXd.

\subsection{Alterations in the Internalization of HER2}

Once anti-HER2 ADCs bind to HER2, the complex is internalized into endosomes, a process that can be promoted by endophillin A2 protein [113]. In fact, it has been observed that the silencing of this protein in HER2+ cells reduces HER2 internalization and decreases the response to trastuzumab and T-DM1 [113]. The processes of ubiquitination and trafficking of HER2 to lysosomes can be altered by its constitutive association with the chaperone HSP90 and, therefore, alter the efficacy of HER2-targeted therapies. In fact, 17-AAG-mediated inhibition of HSP90 in combination with trastuzumab enhances the endocytic uptake of HER2 into lysosomes and its degradation. Furthermore, the 
combination of 17-AAG and trastuzumab has synergistic antiproliferative and apoptotic effects, specifically on HER2+ breast cancer cells [114].

On the other hand, higher recycling of HER2-containing endosomes to the plasma membrane could decrease the arrival of T-DM1 to the lysosome. HER2 is characterized by its rapid recycling, and this process has been observed after the binding of trastuzumab [115]. In a preclinical model of acquired resistance to T-DM1, a greater recycling of T-DM1-HER2 complexes and a reduced intracellular release of DM1 have been observed. However, this model also has lower HER2 levels than the parental line, which also contributes to the resistance phenotype [96].

A recently described mechanism of resistance to T-DM1 is the internalization of T-DM1 through caveolae composed of CAV1, a situation that limits its arrival to lysosomes. In that preclinical model, an overexpression of CAV1 was observed in a cell line with acquired resistance to T-DM1. Furthermore, the colocalization of T-DM1 and CAV1 correlated with a decreased response to T-DM1 in a panel of HER2+ cells. On the other hand, the silencing of CAV1 was not sufficient to re-sensitize the T-DM1-resistant line [98]. In fact, other authors have linked CAV1-dependent internalization with greater sensitivity to T-DM1 [116,117].

\subsection{Alterations in Lysosomes}

The arrival of anti-HER2 ADCs to lysosomes and the processing by lysosomal enzymes is essential for the release of payloads bound to the antibody. Lysosomes are acidic compartments, and their proteolytic capacity depends on the vacuolar proton pump H+-ATPase (V-ATPase) that regulates lysosomal $\mathrm{pH}$. Since lysosomal membranes are impermeable to charged catabolites, Lys-MCC-DM1 requires transport mechanisms from the lysosome to the cytosol. A recent report indicated that an increase in lysosomal $\mathrm{pH}$, as well as a reduction in the activity of lysosomal enzymes, are causes of resistance to T-DM1 [118]. In another model of resistance to T-DM1, a decrease in lysosomal acidification was also reported. In this case, a reduction in intracellular concentrations of Lys-MCC-DM1 was observed because of an aberrant activity of V-ATPase in the lysosomes of resistant cells that decreased the catabolism of T-DM1 and the production of the active catabolite [119].

On the other hand, it has been reported that SLC46A3 is a lysosomal membrane protein that mediates the transport of Lys-MCC-DM1 from the lysosomes to the cell cytoplasm. Loss of SLC46A3 expression has been observed in several models with acquired resistance to T-DM1, and its lentiviral expression restores sensitivity to T-DM1 [120-122].

\subsection{Increased Expression and Activity of Plasma Membrane Drug Efflux Pumps}

Increased expression and/or activity of efflux pumps has been a widely studied mechanism in chemotherapy resistance $[123,124]$. Regarding T-DM1, it has been reported that some pumps of the ABC family can eject the compound Lys-MCC-DM1 to the extracellular medium, preventing it from binding to tubulin. Specifically, it has been reported that alterations in the expression of ABCB1/MDR1/P-gp, ABCC1/MRP1, ABCC2, and ABCG2/BCRP/MXR/ABCP lead to resistance to T-DM1 in preclinical models. In these studies, inhibition of transporter activity restored sensitivity to T-DM1 [96,120,125-127].

\subsection{Increased Production of Ligands and Activation of Alternative RTKS}

In an in vitro study, the addition of the HER3 ligand neuregulin (NRG) inhibited the action of T-DM1 in some HER2+ cell lines [128], due to the consequent dimerization of HER2/HER3 and the activation of the PI3K/AKT pathway. In fact, this effect was reversed by adding pertuzumab, which inhibits this dimerization. These results suggest that ligands such as NRG can affect sensitivity to T-DM1 and therefore be a possible biomarker of refractoriness to T-DM1. A recent study showed that an increase in exogenous NRG1 attenuates the cytotoxic effect of T-DM1 in BT474 cells cultured in 3D. That study also reported that NRG1 mRNA levels positively correlated with an increase in T-DM1 $\mathrm{IC}_{50}$ in a panel of HER2+ cell lines [100]. In fact, in HER2+ breast cancer cell lines with secondary resistance to T-DM1, a higher expression and activation of HER3 and expression of its 
ligand NRG1 was observed. On the other hand, a significant increase in NRG1 transcripts was observed in paired tumor samples that progressed after anti-HER2 therapy, including T-DM1 [100]. In this study, a reduction in HER2 protein levels (in $63.6 \%$ of the paired samples), and even loss of ERBB2 amplification, were also observed after treatment.

Two independent studies have reported that in their models with acquired resistance to T-DM1 and primary resistance to trastuzumab, a decrease in HER2 levels has been accompanied by an increase in EGFR levels [99,120]. However, EGFR silencing was not sufficient to reverse the resistant phenotype [120]. Endo et al. observed that increased EGFR levels led to increased amounts of integrins $(\alpha 5 \beta 1$ and $\alpha \mathrm{V} \beta 3)$, resulting in augmented motility and invasion of resistant cells.

\subsection{Alterations in Proteins Involved in Signaling Pathways}

Sabbaghi et al. reported that in HER2+ breast cancer cell lines sensitive to T-DM1, treatment with that ADC caused an increase in cyclin B1 and arrest in the $\mathrm{G}_{2} / \mathrm{M}$ phase of the cell cycle, a process that triggers the mitotic catastrophe phenotype characteristic of T-DM1 treatment. However, this phenomenon was not observed in cells resistant to T-DM1, where the accumulation of cyclin B1 did not occur. In that study, the silencing of cyclin B1 in the parental lines generated resistance to T-DM1 and the increase in cyclin B1 levels partially sensitized the resistant cell lines [97]. It should be noted that they also observed that in a cohort of 18 HER2+ breast cancer explants, the effect of T-DM1 paralleled the accumulation of cyclin B1.

In another study, an increase in the expression of a mitotic kinase, polo-like kinase 1 (PLK1), has been observed in models resistant to T-DM1 compared to parental cell lines. Inhibition of PLK1, both at the genomic and pharmacological level with volasertib, reversed resistance to T-DM1 in preclinical models [129].

In cells with acquired resistance to T-DM1, it has been reported that decreased levels of PTEN contribute to the resistance phenotype. In fact, the decrease in PTEN levels in the parental line reduced the action of T-DM1 and trastuzumab. In addition, a PI3K inhibitor reversed resistance to T-DM1 caused by loss of PTEN [120]. In fact, the loss and/or decrease of PTEN levels have been related to resistance to trastuzumab [130-132]. In general, deletions in PTEN and activating mutations in the gene that encodes the catalytic subunit of PI3K (PIK3CA) cause the constitutive activation of PI3K/AKT pathway, which relates to resistance to therapies against HER receptors $[3,133]$.

In T-DM1-resistant esophageal carcinoma cells, alterations in the expression of genes involved in cell adhesion and prostaglandin signaling have been observed [134]. These changes promoted alterations in cell morphology, as well as increased migration and survival. However, the specific mechanism by which these expression changes led to resistance to T-DM1 remains to be elucidated.

Activation of STAT3 mediated by overexpression of LIFR has recently been reported to confer resistance to T-DM1. This activation leads to the expression and secretion of factors that induce resistance. STAT3 inhibition re-sensitizes cells to the action of T-DM1, both in vitro and in vivo [135]. On the other hand, increased expression of ROR1 and an increase in cancer stem cells have been related to resistance to T-DM1 [136].

Recently, an increase in resistance to anti-tubulin agents was observed in a HER2+ breast cancer line with acquired resistance to T-DM1. These cells had lower levels of polymerized tubulin and $\beta$ III tubulin and increased baseline aneuploidy. However, the silencing of tubulin $\beta I I I$ in the parental line was not sufficient to generate resistance to T-DM1. The cause of resistance is likely to be multifactorial, including modifications of the microtubule/tubulin complex and chromosomal instability [137].

\section{Treatment Options in the Anti-HER2 ADC Resistance Scenario}

\subsection{Acting on Payload Extrusion}

Some cancer cells develop cross-resistance to a variety of unrelated cytotoxic drugs, a phenomenon known as multidrug resistance (MDR) [124]. ABCB1/MDR1/P-gp is 
an ABC transporter implicated in MDR in several ADC resistance models [120,138-142]. This protein is a membrane glycoprotein that actively pumps cytotoxic agents out from cells, avoiding intracellular drug accumulation $[143,144]$. Kovtun et al. overcame MDR1mediated resistance with a modified linker [145]. They attached DM1 to an antibody using the maleimidyl-based hydrophilic linker $\mathrm{PEG}_{4} \mathrm{Mal}$. The proteolysis of such conjugates in cancer cells resulted in the release of Lys-PEG 4 Mal-DM1 instead of Lys-MCC-DM1. The former is a poor substrate of MDR1, resulting in potency in killing MDR1-expressing cells [145]. MDR1-mediated resistance could also be overcome by combination strategies using inhibitors of MDR transporters. Nevertheless, these inhibitors have limited clinical application because of the role of $\mathrm{ABC}$ transporters in xenobiotic elimination and their expression in non-tumoral cells [146].

\subsection{Redirecting HER2 Internalization and Recycling}

Another strategy for overcoming anti-HER2 ADCs' resistance and increasing their efficacy is to modulate HER2 recycling [115]. Geldanamycin, an inhibitor of HSP90, decreases HER2 recycling and induces localization of HER2 in intracellular vesicles improving degradation of HER2 [115,147]. Indeed, as mentioned before, 17-AAG, another HSP90 inhibitor, in combination with trastuzumab, enhanced HER2 ubiquitination and its downregulation from the cell surface, and also promoted HER2 lysosomal degradation. In addition, the combined therapy potentiated cytotoxicity in HER2+ breast cancer [114]. For that reason, it can be speculated that the combination of an anti-HER2 ADC followed by HSP90 inhibitors may inhibit recycling of ADC-HER2 complexes and direct such complexes for lysosomal degradation.

\subsection{Advances in Anti-HER2 ADC Development in Preclinical Stage}

In addition to the anti-HER2 ADCs under clinical development that have been discussed above, several anti-HER2 ADCs that include cleavable linkers, new conjugation techniques, specific conjugation sites, increased DAR, and/or new cytotoxic agents that possess bystander cytotoxic effect are currently being developed. Those changes improve the stability and efficacy of ADCs compared to T-DM1, and therefore improve their activity in tumors with heterogeneous HER2 expression and/or resistance to T-DM1 [125,148-150].

The current improvements in anti-HER2 ADCs are mainly based in stable DARs with new conjugation technologies and linker chemistry [151]. T-PNU is a new HER2-targeting ADC in which trastuzumab is coupled to a derivative of the highly potent anthracycline PNU-159682 via a non-cleavable peptide linker, by sortase-mediated antibody conjugation (SMAC) technology [148]. Another strategy used to improve anti-HER2 ADCs is the use of two payloads to construct the ADC. Following this strategy, an anti-HER2 ADC containing two different cytotoxic agents (MMAF and MMAE) has been generated with effectiveness in HER2+ breast cancer tumors [125]. Yamazaki and colleagues conjugated both payloads to an anti-HER2 mAb with an N297A mutation by chemoenzymatic conjugation. This approach allowed the simultaneous delivery of two payloads with different features and was able to combat breast cancer HER2 heterogeneity and drug resistance to T-DM1 [125].

Tra-Exa-PSAR10 is a novel ADC anti-HER2 generated by a specific technology called hydrophilic monodisperse polysarcosine (PSAR) drug-linker platform (PSARlink) [149]. With this technology, Coniln and colleagues conjugated trastuzumab to the topoisomerase I inhibitor payload exatecan, achieving a DAR of 8. Tra-Exa-PSAR10 showed higher bystander killing effect than T-DXd and overcame resistance to T-DM1 in HER2+ breast and gastric cancer models.

Robinson and colleagues reported the use of pyridazinediones to selectively re-bridge the native solvent-accessible interstrand disulfide bonds in trastuzumab with MMAE. This method of conjugation generated serum-stable ADCs with a controlled DAR of 4 [150]. Moreover, they reported that this generated MMAE-trastuzumab ADC is potent, selective, and efficacious against HER2+ breast cancer models. 


\subsection{Therapies against HER3}

Overexpression of HER3 is often associated with overexpression of HER2, playing an important role as co-receptor in HER2+ breast cancer [152,153]. Furthermore, breast tumors often show co-expression and positive correlation between HER2 and HER3 levels [154,155].

Elgemtumab or LJM716 is a fully human IgG1 mAb against an epitope located between domains II and IV of the ectodomain of HER3. Treatment with this antibody resensitized cellular models with acquired resistance to T-DM1 to the action of that drug [100].

EV20/MMAF, an ADC against HER3 composed by the mAb EV20 and the payload MMAF [156], has recently demonstrated antitumoral activity in T-DM1-resistant models [157]. In addition, this ADC showed antiproliferative activity in other anti-HER2 therapy resistant settings, including models resistant to trastuzumab, lapatinib, and neratinib [157].

MCLA-128 is a bispecific IgG1 targeting HER2 and HER3. MCLA-128 has a "dock and block" mechanism that blocks the HER2/HER3 heterodimerization. The mechanism of action of this bispecific antibody also includes enhanced ADCC. This antibody has demonstrated its potency in models resistant to T-DM1 [158]. It has also been effective in patients with NRG1 fusions [159]. MCLA-128 is currently being tested in phase I/II clinical trials, which report that MCLA-128 is very well tolerated and safe (NCT03321981, NCT02912949, and NCT04100694).

\subsection{Pan-HER and TKI Thrapies}

Another strategy to overcome anti-HER2 therapy resistance and avoid pathway compensation between ErbB/HER-family receptors is the use of pan-HER antibody mixtures directed against EGFR, HER2, and HER3. The effectiveness of such a strategy has been described in tumors resistant to trastuzumab and T-DM1, demonstrating that such a combination reduces the appearance of relapses compared to other anti-HER2 therapies in clinical use [100,160]. Pan-HER (also called Sym013) is a mixture of $6 \mathrm{mAbs,} \mathrm{comprising} \mathrm{three}$ pairs of synergistic mAbs, each targeting EGFR, HER2, and HER3 [160,161]. This mixture promotes degradation of the receptors and prevents compensatory receptor up-regulation, induces ADCC and complement-dependent cytotoxicity, affects the presence of ligands, and therefore inhibits activation of the PI3K/AKT and MAPK/ERK pathways. Sym013 effectively inhibited growth of HER2+ breast cancer models in vitro and in vivo, including models resistant to HER2-targeted therapeutics such as trastuzumab and T-DM1 [100]. The effect of this compound has been evaluated in different advanced epithelial malignancies (NCT02906670).

A novel HER2-selective irreversible TKI (TAS0728) has recently been described as effective in tumors with acquired resistance to trastuzumab and pertuzumab and to T-DM1. Treatment with TAS0728 resulted in a significant antitumor effect due to HER2-HER3 signal inhibition [162]. Such TKI is currently in phases I/II clinical evaluation.

Neratinib (Nerlynx ${ }^{\circledR}$ ) is an irreversible pan-HER TKI [163-165]. Recently, it has been reported that the cotreatment of T-DM1 with irreversible pan-HER TKIs (such as neratinib and afatinib) enhances the ubiquitination of HER2 and its internalization, and consequently the internalization of T-DM1 and its efficacy. In one patient who showed progression after treatment with T-DM1, the addition of neratinib improved the response to T-DM1 [166]. In 2019, a clinical trial was published showing the efficacy and good tolerability of TDM1 plus neratinib in patients with metastatic HER2+ breast cancer that progressed to trastuzumab, pertuzumab, and taxane [167]. These results underscore the relevance of the double blockade strategy for HER2+ tumors, based on the combination of an antibody acting on the ectodomain plus a TKI.

\subsection{Combination of ADCs with Other Therapies}

Encouraging data suggest that ADCs can enhance antitumor immune response and improve clinical outcomes. Müller et al. reported that T-DM1 treatment combined with anti-CTLA-4/anti-PD-1 was more effective than monotherapy, because the combination triggered innate and adaptive immunity [168]. In fact, antitumor immunity was seen in 
response to T-DM1, but not to trastuzumab, suggesting that DM1 might be responsible for triggering modulatory properties. In line with this observation, the anthracycline payload of T-PNU induced immunogenic cell death [148]. Indeed, the anticancer activity of T-PNU is related to the adaptive immune system. D'Amico et al. demonstrated that the combination of the T-PNU and anti-PD-1 blocking antibodies significantly enhanced antitumor activity, suggesting that stimulation of immunogenic cell death sensitizes to immunotherapy [169]. It has been shown that U3-1402, an ADC targeting HER3, improved the function and infiltration of innate and adaptive immune cells, which subsequently sensitized the tumor to immunotherapy. Accordingly, the combination of this ADC and an anti-PD-1 antibody significantly inhibited tumor growth, even in mice refractory to anti-PD-1 therapy [170]. Currently, combinations of atezolizumab (PD-L1 inhibitor) or pembrolizumab (PD-1 inhibitor) with T-DM1 are under evaluation in several clinicals trials with promising results [171,172].

Inhibition of the antiapoptotic proteins BCL-2 and BCL- $X_{L}$ via navitoclax/ABT-263 significantly enhanced the cytotoxicity of T-DM1 in models derived from advanced and pretreated metastatic breast tumors. Those models, which were highly responsive to the combined therapy, lacked ERBB2 amplification and had low HER2 expression, suggesting that a BCL-2/ $\mathrm{X}_{\mathrm{L}}$ blockade could increase sensitivity of tumors with low HER2 protein levels [173].

\section{Conclusions}

To date, there are twelve FDA-approved ADCs; two of them, T-DM1 and T-DXd, are indicated for HER2+ breast cancer, with the latter also indicated in patients with HER2+ gastric cancer. Despite the unquestionable clinical benefit obtained in patients with HER2+ tumors, a number of these patients develop resistance to T-DM1. In addition, some HER2positive cancers are primarily nonsensitive to T-DM1. Therefore, strategies to overcome such resistances are required.

The development of T-DXd represents one of the first strategies in overcoming resistance to T-DM1 and exemplifies the value of using different chemotherapeutic agents or coupling chemistries to create ADCs that may be effective under circumstances of resistance to T-DM1. Therefore, optimization of each ADC component (the antibody, the linker, and the payload), the conjugation site, and chemistry can improve the efficacy of novel ADCs against tumors refractory to the ADCs currently used in clinics. In addition, identification of the mechanisms of resistance may allow for the development of treatments to overcome them. In this respect, the use of drugs that show preclinical capability to overcome such resistance represents an important initial step.

Author Contributions: Conceptualization, E.D.-R., L.G.-S., A.O. and A.P.; data curation, E.D.-R. and L.G.-S.; funding acquisition, A.O. and A.P.; methodology, E.D.-R., A.P. and L.G.-S.; project administration, E.D.-R., L.G.-S., A.O. and A.P.; resources, A.P. and A.O.; supervision, E.D.-R., L.G.-S., A.O. and A.P.; visualization, E.D.-R. and L.G.-S.; writing—original draft, E.D.-R., L.G.-S. and A.P.; writing - review \& editing, E.D.-R., L.G.-S., A.O. and A.P. All authors have read and agreed to the published version of the manuscript.

Funding: This work was supported by grants from the Ministry of Economy and Competitiveness of Spain (BFU2015-71371-R and PID2020-115605RB-I00), the Instituto de Salud Carlos III through CIBERONC, Junta de Castilla y León (CSI146P20), ALMOM, ACMUMA, UCCTA and the CRIS Cancer Foundation (A.P.), and by the Instituto de Salud Carlos III (PI19/00808), ACEPAIN, and CRIS Cancer Foundation (A.O.). Work carried out in A.P.'s and A.O.'s laboratories received support from the European Community through the Regional Development Funding Program (FEDER). L.G.-S. was the recipient of a predoctoral contract (BES-2016-077748) and is presently contracted with the Cancer Research Foundation of Salamanca University (FICUS).

Conflicts of Interest: A.O. is an employee of Servier-Symphogen. The other authors declare no conflict of interest. 


\section{References}

1. Hynes, N.E.; Lane, H.A. ERBB receptors and cancer: The complexity of targeted inhibitors. Nat. Rev. Cancer 2005, 5, 341-354. [CrossRef]

2. Esparis-Ogando, A.; Montero, J.C.; Arribas, J.; Ocana, A.; Pandiella, A. Targeting the EGF/HER Ligand-Receptor System in Cancer. Curr. Pharm. Des. 2016, 22, 5887-5898. [CrossRef]

3. Arteaga, C.L.; Engelman, J.A. ERBB receptors: From oncogene discovery to basic science to mechanism-based cancer therapeutics. Cancer Cell 2014, 25, 282-303. [CrossRef] [PubMed]

4. Slamon, D.J.; Clark, G.M.; Wong, S.G.; Levin, W.J.; Ullrich, A.; McGuire, W.L. Human breast cancer: Correlation of relapse and survival with amplification of the HER-2/neu oncogene. Science 1987, 235, 177-182. [CrossRef]

5. Rinnerthaler, G.; Gampenrieder, S.P.; Greil, R. HER2 Directed Antibody-Drug-Conjugates beyond T-DM1 in Breast Cancer. Int. J. Mol. Sci. 2019, 20, 1115. [CrossRef]

6. Ferraro, E.; Drago, J.Z.; Modi, S. Implementing antibody-drug conjugates (ADCs) in HER2-positive breast cancer: State of the art and future directions. Breast Cancer Res. 2021, 23, 84. [CrossRef] [PubMed]

7. Drago, J.Z.; Modi, S.; Chandarlapaty, S. Unlocking the potential of antibody-drug conjugates for cancer therapy. Nat. Rev. Clin. Oncol. 2021, 18, 327-344. [CrossRef]

8. Baah, S.; Laws, M.; Rahman, K.M. Antibody-Drug Conjugates-A Tutorial Review. Molecules 2021, 26, 2943. [CrossRef] [PubMed]

9. Oroudjev, E.; Lopus, M.; Wilson, L.; Audette, C.; Provenzano, C.; Erickson, H.; Kovtun, Y.; Chari, R.; Jordan, M.A. Maytansinoidantibody conjugates induce mitotic arrest by suppressing microtubule dynamic instability. Mol. Cancer Ther. 2010, 9, 2700-2713. [CrossRef]

10. Remillard, S.; Rebhun, L.I.; Howie, G.A.; Kupchan, S.M. Antimitotic activity of the potent tumor inhibitor maytansine. Science 1975, 189, 1002-1005. [CrossRef]

11. Verma, S.; Miles, D.; Gianni, L.; Krop, I.E.; Welslau, M.; Baselga, J.; Pegram, M.; Oh, D.Y.; Dieras, V.; Guardino, E.; et al. Trastuzumab emtansine for HER2-positive advanced breast cancer. N. Engl. J. Med. 2012, 367, 1783-1791. [CrossRef]

12. Doronina, S.O.; Toki, B.E.; Torgov, M.Y.; Mendelsohn, B.A.; Cerveny, C.G.; Chace, D.F.; DeBlanc, R.L.; Gearing, R.P.; Bovee, T.D.; Siegall, C.B.; et al. Development of potent monoclonal antibody auristatin conjugates for cancer therapy. Nat. Biotechnol. 2003, 21, 778-784. [CrossRef] [PubMed]

13. Poncet, J. The dolastatins, a family of promising antineoplastic agents. Curr. Pharm. Des. 1999, 5, 139-162. [PubMed]

14. Minami, H.; Fujii, H.; Igarashi, T.; Itoh, K.; Tamanoi, K.; Oguma, T.; Sasaki, Y. Phase I and pharmacological study of a new camptothecin derivative, exatecan mesylate (DX-8951f), infused over 30 minutes every three weeks. Clin. Cancer Res. 2001, 7, 3056-3064.

15. Mitsui, I.; Kumazawa, E.; Hirota, Y.; Aonuma, M.; Sugimori, M.; Ohsuki, S.; Uoto, K.; Ejima, A.; Terasawa, H.; Sato, K. A new water-soluble camptothecin derivative, DX-8951f, exhibits potent antitumor activity against human tumors in vitro and in vivo Jpn. J. Cancer Res. 1995, 86, 776-782. [CrossRef]

16. Patil, P.C.; Satam, V.; Lee, M. A Short Review on the Synthetic Strategies of Duocarmycin Analogs that are Powerful DNA Alkylating Agents. Anticancer Agents Med. Chem. 2015, 15, 616-630. [CrossRef]

17. Elgersma, R.C.; Coumans, R.G.; Huijbregts, T.; Menge, W.M.; Joosten, J.A.; Spijker, H.J.; de Groot, F.M.; van der Lee, M.M.; Ubink, R.; van den Dobbelsteen, D.J.; et al. Design, Synthesis, and Evaluation of Linker-Duocarmycin Payloads: Toward Selection of HER2-Targeting Antibody-Drug Conjugate SYD985. Mol. Pharm. 2015, 12, 1813-1835. [CrossRef]

18. Hafeez, U.; Parakh, S.; Gan, H.K.; Scott, A.M. Antibody-Drug Conjugates for Cancer Therapy. Molecules 2020, $25,4764$. [CrossRef] [PubMed]

19. Jain, N.; Smith, S.W.; Ghone, S.; Tomczuk, B. Current ADC Linker Chemistry. Pharm. Res. 2015, 32, 3526-3540. [CrossRef]

20. Tsuchikama, K.; An, Z. Antibody-drug conjugates: Recent advances in conjugation and linker chemistries. Protein Cell 2018, 9 , 33-46. [CrossRef]

21. Beck, A.; Goetsch, L.; Dumontet, C.; Corvaïa, N. Strategies and challenges for the next generation of antibody-drug conjugates. Nat. Rev. Drug Discov. 2017, 16, 315-337. [CrossRef] [PubMed]

22. Shen, B.Q.; Xu, K.; Liu, L.; Raab, H.; Bhakta, S.; Kenrick, M.; Parsons-Reponte, K.L.; Tien, J.; Yu, S.F.; Mai, E.; et al. Conjugation site modulates the in vivo stability and therapeutic activity of antibody-drug conjugates. Nat. Biotechnol. 2012, 30, 184-189. [CrossRef]

23. Bargh, J.D.; Isidro-Llobet, A.; Parker, J.S.; Spring, D.R. Cleavable linkers in antibody-drug conjugates. Chem. Soc. Rev. 2019, 48, 4361-4374. [CrossRef]

24. Hall, E.J. The bystander effect. Health Phys. 2003, 85, 31-35. [CrossRef] [PubMed]

25. McCombs, J.R.; Owen, S.C. Antibody drug conjugates: Design and selection of linker, payload and conjugation chemistry. AAPS J. 2015, 17, 339-351. [CrossRef] [PubMed]

26. Junutula, J.R.; Raab, H.; Clark, S.; Bhakta, S.; Leipold, D.D.; Weir, S.; Chen, Y.; Simpson, M.; Tsai, S.P.; Dennis, M.S.; et al. Site-specific conjugation of a cytotoxic drug to an antibody improves the therapeutic index. Nat. Biotechnol. 2008, 26, 925-932. [CrossRef] [PubMed]

27. Axup, J.Y.; Bajjuri, K.M.; Ritland, M.; Hutchins, B.M.; Kim, C.H.; Kazane, S.A.; Halder, R.; Forsyth, J.S.; Santidrian, A.F.; Stafin, K.; et al. Synthesis of site-specific antibody-drug conjugates using unnatural amino acids. Proc. Natl. Acad. Sci. USA 2012, 109, 16101-16106. [CrossRef] [PubMed] 
28. Zimmerman, E.S.; Heibeck, T.H.; Gill, A.; Li, X.; Murray, C.J.; Madlansacay, M.R.; Tran, C.; Uter, N.T.; Yin, G.; Rivers, P.J.; et al. Production of site-specific antibody-drug conjugates using optimized non-natural amino acids in a cell-free expression system. Bioconjug. Chem. 2014, 25, 351-361. [CrossRef]

29. Conner, S.D.; Schmid, S.L. Regulated portals of entry into the cell. Nature 2003, 422, 37-44. [CrossRef] [PubMed]

30. Ritchie, M.; Tchistiakova, L.; Scott, N. Implications of receptor-mediated endocytosis and intracellular trafficking dynamics in the development of antibody drug conjugates. MAbs 2013, 5, 13-21. [CrossRef]

31. Kalim, M.; Chen, J.; Wang, S.; Lin, C.; Ullah, S.; Liang, K.; Ding, Q.; Chen, S.; Zhan, J. Intracellular trafficking of new anticancer therapeutics: Antibody-drug conjugates. Drug Des. Dev. Ther. 2017, 11, 2265-2276. [CrossRef]

32. Chalouni, C.; Doll, S. Fate of Antibody-Drug Conjugates in Cancer Cells. J. Exp. Clin. Cancer Res. 2018, 37, 20. [CrossRef] [PubMed]

33. Staudacher, A.H.; Brown, M.P. Antibody drug conjugates and bystander killing: Is antigen-dependent internalisation required? Br. J. Cancer 2017, 117, 1736-1742. [CrossRef]

34. Li, F.; Emmerton, K.K.; Jonas, M.; Zhang, X.; Miyamoto, J.B.; Setter, J.R.; Nicholas, N.D.; Okeley, N.M.; Lyon, R.P.; Benjamin, D.R.; et al. Intracellular Released Payload Influences Potency and Bystander-Killing Effects of Antibody-Drug Conjugates in Preclinical Models. Cancer Res. 2016, 76, 2710-2719. [CrossRef] [PubMed]

35. García-Alonso, S.; Ocaña, A.; Pandiella, A. Trastuzumab Emtansine: Mechanisms of Action and Resistance, Clinical Progress, and Beyond. Trends Cancer 2020, 6, 130-146. [CrossRef]

36. Lewis Phillips, G.D.; Li, G.; Dugger, D.L.L.; Crocker, L.M.; Parsons, K.L.; Mai, E.; Blattler, W.A.; Lambert, J.M.; Chari, R.V.; Lutz, R.J.; et al. Targeting HER2-positive breast cancer with trastuzumab-DM1, an antibody-cytotoxic drug conjugate. Cancer Res. 2008, 68, 9280-9290. [CrossRef] [PubMed]

37. Junttila, T.T.; Li, G.; Parsons, K.; Phillips, G.L.; Sliwkowski, M.X. Trastuzumab-DM1 (T-DM1) retains all the mechanisms of action of trastuzumab and efficiently inhibits growth of lapatinib insensitive breast cancer. Breast Cancer Res. Treat. 2011, 128, 347-356. [CrossRef] [PubMed]

38. Barok, M.; Joensuu, H.; Isola, J. Trastuzumab emtansine: Mechanisms of action and drug resistance. Breast Cancer Res. 2014, 16, 209. [CrossRef]

39. Barok, M.; Tanner, M.; Köninki, K.; Isola, J. Trastuzumab-DM1 causes tumour growth inhibition by mitotic catastrophe in trastuzumab-resistant breast cancer cells in vivo. Breast Cancer Res. 2011, 13, R46. [CrossRef]

40. Vakifahmetoglu, H.; Olsson, M.; Zhivotovsky, B. Death through a tragedy: Mitotic catastrophe. Cell Death Differ. 2008, 15, 1153-1162. [CrossRef]

41. Krop, I.E.; Kim, S.B.; Gonzalez-Martin, A.; LoRusso, P.M.; Ferrero, J.M.; Smitt, M.; Yu, R.; Leung, A.C.; Wildiers, H.; TH3RESA Study Collaborators. Trastuzumab emtansine versus treatment of physician's choice for pretreated HER2-positive advanced breast cancer (TH3RESA): A randomised, open-label, phase 3 trial. Lancet Oncol. 2014, 15, 689-699. [CrossRef]

42. von Minckwitz, G.; Huang, C.S.; Mano, M.S.; Loibl, S.; Mamounas, E.P.; Untch, M.; Wolmark, N.; Rastogi, P.; Schneeweiss, A.; Redondo, A.; et al. Trastuzumab Emtansine for Residual Invasive HER2-Positive Breast Cancer. N. Engl. J. Med. 2019, 380, 617-628. [CrossRef]

43. Perez, E.A.; Barrios, C.; Eiermann, W.; Toi, M.; Im, Y.H.; Conte, P.; Martin, M.; Pienkowski, T.; Pivot, X.; Burris, H., III; et al Trastuzumab Emtansine With or Without Pertuzumab Versus Trastuzumab Plus Taxane for Human Epidermal Growth Factor Receptor 2-Positive, Advanced Breast Cancer: Primary Results From the Phase III MARIANNE Study. J. Clin. Oncol. 2017, 35, 141-148. [CrossRef]

44. Ocana, A.; Amir, E.; Pandiella, A. Dual targeting of HER2-positive breast cancer with trastuzumab emtansine and pertuzumab: Understanding clinical trial results. Oncotarget 2018, 9, 31915-31919. [CrossRef]

45. Battisti, N.M.L.; Rogerson, F.; Lee, K.; Shepherd, S.; Mohammed, K.; Turner, N.; McGrath, S.; Okines, A.; Parton, M.; Johnston, S.; et al. Safety and efficacy of T-DM1 in patients with advanced HER2-positive breast cancer The Royal Marsden experience. Cancer Treat. Res. Commun. 2020, 24, 100188. [CrossRef]

46. Dieras, V.; Miles, D.; Verma, S.; Pegram, M.; Welslau, M.; Baselga, J.; Krop, I.E.; Blackwell, K.; Hoersch, S.; Xu, J.; et al. Trastuzumab emtansine versus capecitabine plus lapatinib in patients with previously treated HER2-positive advanced breast cancer (EMILIA): A descriptive analysis of final overall survival results from a randomised, open-label, phase 3 trial. Lancet Oncol. 2017, 18, 732-742. [CrossRef]

47. Ogitani, Y.; Aida, T.; Hagihara, K.; Yamaguchi, J.; Ishii, C.; Harada, N.; Soma, M.; Okamoto, H.; Oitate, M.; Arakawa, S.; et al. DS-8201a, A Novel HER2-Targeting ADC with a Novel DNA Topoisomerase I Inhibitor, Demonstrates a Promising Antitumor Efficacy with Differentiation from T-DM1. Clin. Cancer Res. 2016, 22, 5097-5108. [CrossRef]

48. Ogitani, Y.; Hagihara, K.; Oitate, M.; Naito, H.; Agatsuma, T. Bystander killing effect of DS-8201a, a novel anti-human epidermal growth factor receptor 2 antibody-drug conjugate, in tumors with human epidermal growth factor receptor 2 heterogeneity. Cancer Sci 2016, 107, 1039-1046. [CrossRef] [PubMed]

49. Diéras, V.; Deluche, E.; Lusque, A.; Pistilli, B.; Bachelot, T.; Pierga, J.-Y.; Viret, F.; Levy, C.; Salabert, L.; Le Du, F.; et al. Trastuzumab deruxtecan (T-DXd) for advanced breast cancer patients (ABC), regardless HER2 status: A phase II study with biomarkers analysis (DAISY). SABCS 2021, PD8-02.

50. Modi, S.; Saura, C.; Yamashita, T.; Park, Y.H.; Kim, S.B.; Tamura, K.; Andre, F.; Iwata, H.; Ito, Y.; Tsurutani, J.; et al. Trastuzumab Deruxtecan in Previously Treated HER2-Positive Breast Cancer. N. Engl. J. Med. 2020, 382, 610-621. [CrossRef] [PubMed] 
51. Tamura, K.; Tsurutani, J.; Takahashi, S.; Iwata, H.; Krop, I.E.; Redfern, C.; Sagara, Y.; Doi, T.; Park, H.; Murthy, R.K.; et al. Trastuzumab deruxtecan (DS-8201a) in patients with advanced HER2-positive breast cancer previously treated with trastuzumab emtansine: A dose-expansion, phase 1 study. Lancet Oncol. 2019, 20, 816-826. [CrossRef]

52. Iwata, T.N.; Sugihara, K.; Wada, T.; Agatsuma, T. [Fam-] trastuzumab deruxtecan (DS-8201a)-induced antitumor immunity is facilitated by the anti-CTLA-4 antibody in a mouse model. PLoS ONE 2019, 14, e0222280. [CrossRef]

53. Jerusalem, G.H.M.; Park, Y.H.; Yamashita, T.; Hurvitz, S.A.; Modi, S.; Andre, F.; Krop, I.E.; Gonzalez, X.; Hall, P.S.; You, B.; et al. Trastuzumab deruxtecan (T-DXd) in patients with HER2+ metastatic breast cancer with brain metastases: A subgroup analysis of the DESTINY-Breast01 trial. J. Clin. Oncol. 2021, 39, 526. [CrossRef]

54. Yao, H.P.; Zhao, H.; Hudson, R.; Tong, X.M.; Wang, M.H. Duocarmycin-based antibody-drug conjugates as an emerging biotherapeutic entity for targeted cancer therapy: Pharmaceutical strategy and clinical progress. Drug Discov. Today 2021, 26, 1857-1874. [CrossRef]

55. Yasuzawa, T.; Iida, T.; Muroi, K.; Ichimura, M.; Takahashi, K.; Sano, H. Structures of duocarmycins, novel antitumor antibiotics produced by Streptomyces sp. Chem. Pharm. Bull. 1988, 36, 3728-3731. [CrossRef]

56. Boger, D.L.; Johnson, D.S. CC-1065 and the duocarmycins: Unraveling the keys to a new class of naturally derived DNA alkylating agents. Proc. Natl. Acad. Sci. USA 1995, 92, 3642-3649. [CrossRef]

57. Boger, D.L.; Johnson, D.S.; Palanki, M.S.; Kitos, P.A.; Chang, J.; Dowell, P. Evaluation of functional analogs of CC-1065 and the duocarmycins incorporating the cross-linking 9a-chloromethyl-1,2,9,9a-tetrahydrocyclopropa[c]benz[e]indol-4-on e (C2BI) alkylation subunit. Bioorg. Med. Chem. 1993, 1, 27-38. [CrossRef]

58. Nadal-Serrano, M.; Morancho, B.; Escrivá-de-Romaní, S.; Morales, C.B.; Luque, A.; Escorihuela, M.; Espinosa Bravo, M.; Peg, V.; Dijcks, F.A.; Dokter, W.H.A.; et al. The Second Generation Antibody-Drug Conjugate SYD985 Overcomes Resistances to T-DM1. Cancers 2020, 12, 670. [CrossRef] [PubMed]

59. Banerji, U.; van Herpen, C.M.L.; Saura, C.; Thistlethwaite, F.; Lord, S.; Moreno, V.; Macpherson, I.R.; Boni, V.; Rolfo, C.; de Vries, E.G.E.; et al. Trastuzumab duocarmazine in locally advanced and metastatic solid tumours and HER2-expressing breast cancer: A phase 1 dose-escalation and dose-expansion study. Lancet Oncol. 2019, 20, 1124-1135. [CrossRef]

60. Nagaraja Shastri, P.; Zhu, J.; Skidmore, L.; Liang, X.; Ji, Y.; Gu, Y.; Tian, F.; Yao, S.; Xia, G. Nonclinical Development of Nextgeneration Site-specific HER2-targeting Antibody-drug Conjugate (ARX788) for Breast Cancer Treatment. Mol. Cancer Ther. 2020, 19, 1822-1832. [CrossRef]

61. Skidmore, L.; Sakamuri, S.; Knudsen, N.A.; Hewet, A.G.; Milutinovic, S.; Barkho, W.; Biroc, S.L.; Kirtley, J.; Marsden, R.; Storey, K.; et al. ARX788, a Site-specific Anti-HER2 Antibody-Drug Conjugate, Demonstrates Potent and Selective Activity in HER2-low and T-DM1-resistant Breast and Gastric Cancers. Mol. Cancer Ther. 2020, 19, 1833-1843. [CrossRef]

62. Barok, M.; Le Joncour, V.; Martins, A.; Isola, J.; Salmikangas, M.; Laakkonen, P.; Joensuu, H. ARX788, a novel anti-HER2 antibody-drug conjugate, shows anti-tumor effects in preclinical models of trastuzumab emtansine-resistant HER2-positive breast cancer and gastric cancer. Cancer Lett. 2020, 473, 156-163. [CrossRef]

63. Jiang, J.; Li, S.; Shan, X.; Wang, L.; Ma, J.; Huang, M.; Dong, L.; Chen, F. Preclinical safety profile of disitamab vedotina novel anti-HER2 antibody conjugated with MMAE. Toxicol. Lett. 2020, 324, 30-37. [CrossRef]

64. Li, L.; Xu, M.Z.; Wang, L.; Jiang, J.; Dong, L.H.; Chen, F.; Dong, K.; Song, H.F. Conjugating MMAE to a novel anti-HER2 antibody for selective targeted delivery. Eur. Rev. Med. Pharm. Sci. 2020, 24, 12929-12937. [CrossRef]

65. Yao, X.; Jiang, J.; Wang, X.; Huang, C.; Li, D.; Xie, K.; Xu, Q.; Li, H.; Li, Z.; Lou, L.; et al. A novel humanized anti-HER2 antibody conjugated with MMAE exerts potent anti-tumor activity. Breast Cancer Res. Treat. 2015, 153, 123-133. [CrossRef] [PubMed]

66. Huang, L.; Wang, R.; Xie, K.; Zhang, J.; Tao, F.; Pi, C.; Feng, Y.; Gu, H.; Fang, J. A HER2 target antibody drug conjugate combined with anti-PD-(L)1 treatment eliminates hHER2+ tumors in hPD-1 transgenic mouse model and contributes immune memory formation. Breast Cancer Res. Treat. 2021. [CrossRef]

67. Sheng, X.; Yan, X.; Wang, L.; Shi, Y.; Yao, X.; Luo, H.; Shi, B.; Liu, J.; He, Z.; Yu, G.; et al. Open-label, Multicenter, Phase II Study of RC48-ADC, a HER2-Targeting Antibody-Drug Conjugate, in Patients with Locally Advanced or Metastatic Urothelial Carcinoma. Clin. Cancer Res. 2021, 27, 43-51. [CrossRef] [PubMed]

68. Xu, Y.; Wang, Y.; Gong, J.; Zhang, X.; Peng, Z.; Sheng, X.; Mao, C.; Fan, Q.; Bai, Y.; Ba, Y.; et al. Phase I study of the recombinant humanized anti-HER2 monoclonal antibody-MMAE conjugate RC48-ADC in patients with HER2-positive advanced solid tumors. Gastric Cancer 2021, 24, 913-925. [CrossRef]

69. Park, Y.H.; Ahn, H.K.; Kim, J.-Y.; Ahn, J.S.; Im, Y.-H.; Kim, S.-H.; Lee, S.; Chung, H.-S.; Park, S.J. First-in-human phase I study of ALT-P7, a HER2-targeting antibody-drug conjugate in patients with HER2-positive advanced breast cancer. J. Clin. Oncol. 2020, 38, 3551. [CrossRef]

70. Li, H.; Zhang, X.; Xu, Z.; Li, L.; Liu, W.; Dai, Z.; Zhao, Z.; Xiao, L.; Li, H.; Hu, C. Preclinical evaluation of MRG002, a novel HER2-targeting antibody-drug conjugate with potent antitumor activity against HER2-positive solid tumors. Antib. Ther. 2021, 4, 175-184. [CrossRef]

71. Li, J.; Guo, Y.; Xue, J.; Peng, W.; Ge, X.; Zhao, W.; Dai, C.; Xue, L.; Tang, W.; Hu, C. First-in-human phase I study of anti-HER2 ADC MRG002 in patients with relapsed/refractory solid tumors. J. Clin. Oncol. 2020, 38, TPS1101. [CrossRef]

72. Lopez, D.M.; Barve, M.; Wang, J.; Bullock, A.J.; Pectasides, E.; Vaishampayan, U.; Spira, A.I.; Ulahannan, S.; Patnaik, A.; Sanborn, R.E.; et al. Abstract B005: A phase I study of A166, a novel anti-HER2 antibody-drug conjugate (ADC), in patients with locally advanced/metastatic solid tumors. Mol. Cancer Ther. 2019, 18, B005. [CrossRef] 
73. Betts, A.; Clark, T.; Jasper, P.; Tolsma, J.; van der Graaf, P.H.; Graziani, E.I.; Rosfjord, E.; Sung, M.; Ma, D.; Barletta, F. Use of translational modeling and simulation for quantitative comparison of PF-06804103, a new generation HER2 ADC, with Trastuzumab-DM1. J. Pharm. Pharm. 2020, 47, 513-526. [CrossRef] [PubMed]

74. Graziani, E.I.; Sung, M.; Ma, D.; Narayanan, B.; Marquette, K.; Puthenveetil, S.; Tumey, L.N.; Bikker, J.; Casavant, J.; Bennett, E.M.; et al. PF-06804103, A Site-specific Anti-HER2 Antibody-Drug Conjugate for the Treatment of HER2-expressing Breast, Gastric, and Lung Cancers. Mol. Cancer Ther. 2020, 19, 2068-2078. [CrossRef] [PubMed]

75. Meric-Bernstam, F.; Calvo, E.; Moreno, V.; Chung, H.C.; Park, Y.H.; Bang, Y.-J.; Rosen, L.S.; Mita, M.M.; Garrido-Laguna, I.; Leung, A.C.F.; et al. A phase I dose escalation study evaluating the safety and tolerability of a novel anti-HER2 antibody-drug conjugate (PF-06804103) in patients with HER2-positive solid tumors. J. Clin. Oncol. 2020, 38, 1039. [CrossRef]

76. Faria, M.; Peay, M.; Lam, B.; Ma, E.; Yuan, M.; Waldron, M.; Mylott, W.R., Jr.; Liang, M.; Rosenbaum, A.I. Multiplex LC-MS/MS Assays for Clinical Bioanalysis of MEDI4276, an Antibody-Drug Conjugate of Tubulysin Analogue Attached via Cleavable Linker to a Biparatopic Humanized Antibody against HER-2. Antibodies 2019, 8, 11. [CrossRef]

77. Oganesyan, V.; Peng, L.; Bee, J.S.; Li, J.; Perry, S.R.; Comer, F.; Xu, L.; Cook, K.; Senthil, K.; Clarke, L.; et al. Structural insights into the mechanism of action of a biparatopic anti-HER2 antibody. J. Biol. Chem. 2018, 293, 8439-8448. [CrossRef]

78. Pegram, M.D.; Hamilton, E.P.; Tan, A.R.; Storniolo, A.M.; Balic, K.; Rosenbaum, A.I.; Liang, M.; He, P.; Marshall, S.; Scheuber, A.; et al. First-in-Human, Phase 1 Dose-Escalation Study of Biparatopic Anti-HER2 Antibody-Drug Conjugate MEDI4276 in Patients with HER2-positive Advanced Breast or Gastric Cancer. Mol. Cancer Ther. 2021, 20, 1442-1453. [CrossRef]

79. Lee, B.I.; Park, M.H.; Byeon, J.J.; Shin, S.H.; Choi, J.; Park, Y.; Park, Y.H.; Chae, J.; Shin, Y.G. Quantification of an AntibodyConjugated Drug in Fat Plasma by an Affinity Capture LC-MS/MS Method for a Novel Prenyl Transferase-Mediated Site-Specific Antibody-Drug Conjugate. Molecules 2020, 25, 1515. [CrossRef]

80. Kunte, S.; Abraham, J.; Montero, A.J. Novel HER2-targeted therapies for HER2-positive metastatic breast cancer. Cancer 2020, 126, 4278-4288. [CrossRef]

81. Hamblett, K.J.; Hammond, P.W.; Barnscher, S.D.; Fung, V.K.; Davies, R.H.; Wickman, G.R.; Hernandez, A.; Ding, T.; Galey, A.S.; Winters, G.C.; et al. Abstract 3914: ZW49, a HER2-targeted biparatopic antibody-drug conjugate for the treatment of HER2-expressing cancers. Cancer Res. 2018, 78, 3914. [CrossRef]

82. Hong, R.; Xia, W.; Wang, L.; Lee, K.; Lu, Q.; Jiang, K.; Li, S.; Yu, J.; Wei, J.; Tang, W.; et al. Safety, tolerability, and pharmacokinetics of BAT8001 in patients with HER2-positive breast cancer: An open-label, dose-escalation, phase I study. Cancer Commun. 2021, 41 , 171-182. [CrossRef]

83. Tymon-Rosario, J.; Bonazzoli, E.; Bellone, S.; Manzano, A.; Pelligra, S.; Guglielmi, A.; Gnutti, B.; Nagarkatti, N.; Zeybek, B.; Manara, P.; et al. DHES0815A, a novel antibody-drug conjugate targeting HER2/neu, is highly active against uterine serous carcinomas in vitro and in vivo. Gynecol. Oncol. 2021, 163, 334-341. [CrossRef]

84. Burris, H.A., III; Rugo, H.S.; Vukelja, S.J.; Vogel, C.L.; Borson, R.A.; Limentani, S.; Tan-Chiu, E.; Krop, I.E.; Michaelson, R.A.; Girish, S.; et al. Phase II study of the antibody drug conjugate trastuzumab-DM1 for the treatment of human epidermal growth factor receptor 2 (HER2)-positive breast cancer after prior HER2-directed therapy. J. Clin. Oncol. 2011, 29, 398-405. [CrossRef]

85. LoRusso, P.M.; Weiss, D.; Guardino, E.; Girish, S.; Sliwkowski, M.X. Trastuzumab emtansine: A unique antibody-drug conjugate in development for human epidermal growth factor receptor 2-positive cancer. Clin. Cancer Res. 2011, 17, 6437-6447. [CrossRef] [PubMed]

86. Bon, G.; Pizzuti, L.; Laquintana, V.; Loria, R.; Porru, M.; Marchiò, C.; Krasniqi, E.; Barba, M.; Maugeri-Saccà, M.; Gamucci, T.; et al. Loss of HER2 and decreased T-DM1 efficacy in HER2 positive advanced breast cancer treated with dual HER2 blockade: The SePHER Study. J. Exp. Clin. Cancer Res. 2020, 39, 279. [CrossRef]

87. Van Raemdonck, E.; Floris, G.; Berteloot, P.; Laenen, A.; Vergote, I.; Wildiers, H.; Punie, K.; Neven, P. Efficacy of anti-HER2 therapy in metastatic breast cancer by discordance of HER2 expression between primary and metastatic breast cancer. Breast Cancer Res. Treat. 2021, 185, 183-194. [CrossRef]

88. Schrijver, W.; Suijkerbuijk, K.P.M.; van Gils, C.H.; van der Wall, E.; Moelans, C.B.; van Diest, P.J. Receptor Conversion in Distant Breast Cancer Metastases: A Systematic Review and Meta-analysis. J. Natl. Cancer Inst. 2018, 110, 568-580. [CrossRef] [PubMed]

89. Aurilio, G.; Disalvatore, D.; Pruneri, G.; Bagnardi, V.; Viale, G.; Curigliano, G.; Adamoli, L.; Munzone, E.; Sciandivasci, A.; De Vita, F.; et al. A meta-analysis of oestrogen receptor, progesterone receptor and human epidermal growth factor receptor 2 discordance between primary breast cancer and metastases. Eur. J. Cancer 2014, 50, 277-289. [CrossRef]

90. Lower, E.E.; Khan, S.; Kennedy, D.; Baughman, R.P. Discordance of the estrogen receptor and HER-2/neu in breast cancer from primary lesion to first and second metastatic site. Breast Cancer Targets Ther. 2017, 9, 515. [CrossRef]

91. Niikura, N.; Liu, J.; Hayashi, N.; Mittendorf, E.A.; Gong, Y.; Palla, S.L.; Tokuda, Y.; Gonzalez-Angulo, A.M.; Hortobagyi, G.N.; Ueno, N.T. Loss of human epidermal growth factor receptor 2 (HER2) expression in metastatic sites of HER2-overexpressing primary breast tumors. J. Clin. Oncol. 2012, 30, 593-599. [CrossRef] [PubMed]

92. Mittendorf, E.A.; Wu, Y.; Scaltriti, M.; Meric-Bernstam, F.; Hunt, K.K.; Dawood, S.; Esteva, F.J.; Buzdar, A.U.; Chen, H.; Eksambi, S.; et al. Loss of HER2 amplification following trastuzumab-based neoadjuvant systemic therapy and survival outcomes. Clin. Cancer Res. 2009, 15, 7381-7388. [CrossRef] [PubMed]

93. Hurvitz, S.A.; Martin, M.; Jung, K.H.; Huang, C.S.; Harbeck, N.; Valero, V.; Stroyakovskiy, D.; Wildiers, H.; Campone, M.; Boileau, J.F.; et al. Neoadjuvant Trastuzumab Emtansine and Pertuzumab in Human Epidermal Growth Factor Receptor 2-Positive Breast Cancer: Three-Year Outcomes From the Phase III KRISTINE Study. J. Clin. Oncol. 2019, 37, 2206-2216. [CrossRef] 
94. Seo, S.; Ryu, M.H.; Park, Y.S.; Ahn, J.Y.; Park, Y.; Park, S.R.; Ryoo, B.Y.; Lee, G.H.; Jung, H.Y.; Kang, Y.K. Loss of HER2 positivity after anti-HER2 chemotherapy in HER2-positive gastric cancer patients: Results of the GASTric cancer HER2 reassessment study 3 (GASTHER3). Gastric Cancer 2019, 22, 527-535. [CrossRef]

95. Sakai, H.; Tsurutani, J.; Iwasa, T.; Komoike, Y.; Sakai, K.; Nishio, K.; Nakagawa, K. HER2 genomic amplification in circulating tumor DNA and estrogen receptor positivity predict primary resistance to trastuzumab emtansine (T-DM1) in patients with HER2-positive metastatic breast cancer. Breast Cancer 2018, 25, 605-613. [CrossRef]

96. Loganzo, F.; Tan, X.; Sung, M.; Jin, G.; Myers, J.S.; Melamud, E.; Wang, F.; Diesl, V.; Follettie, M.T.; Musto, S. Tumor cells chronically treated with a trastuzumab-maytansinoid antibody-drug conjugate develop varied resistance mechanisms but respond to alternate treatments. Mol. Cancer Ther. 2015, 14, 952-963. [CrossRef]

97. Sabbaghi, M.; Gil-Gómez, G.; Guardia, C.; Servitja, S.; Arpi, O.; García-Alonso, S.; Menéndez, S.; Arumi-Uria, M.; Serrano, L.; Salido, M. Defective cyclin B1 induction in trastuzumab-emtansine (T-DM1) acquired resistance in HER2-positive breast cancer. Clin. Cancer Res. 2017, 23, 7006-7019. [CrossRef] [PubMed]

98. Sung, M.; Tan, X.; Lu, B.; Golas, J.; Hosselet, C.; Wang, F.; Tylaska, L.; King, L.; Zhou, D.; Dushin, R. Caveolae-mediated endocytosis as a novel mechanism of resistance to trastuzumab emtansine (T-DM1). Mol. Cancer Ther. 2018, 17, 243-253. [CrossRef]

99. Endo, Y.; Shen, Y.; Youssef, L.A.; Mohan, N.; Wu, W.J. T-DM1-resistant cells gain high invasive activity via EGFR and integrin cooperated pathways. $m A$ bs 2018, 10, 1003-1017. [CrossRef] [PubMed]

100. Schwarz, L.J.; Hutchinson, K.E.; Rexer, B.N.; Estrada, M.V.; Gonzalez Ericsson, P.I.; Sanders, M.E.; Dugger, T.C.; Formisano, L.; Guerrero-Zotano, A.; Red-Brewer, M. An ERBB1-3 neutralizing antibody mixture with high activity against drug-resistant HER2+ breast cancers with ERBB ligand overexpression. J. Natl. Cancer Inst. 2017, 109, djx065. [CrossRef] [PubMed]

101. Scaltriti, M.; Rojo, F.; Ocaña, A.; Anido, J.; Guzman, M.; Cortes, J.; Di Cosimo, S.; Matias-Guiu, X.; Ramon y Cajal, S.; Arribas, J.; et al. Expression of p95HER2, a truncated form of the HER2 receptor, and response to anti-HER2 therapies in breast cancer. J. Natl. Cancer Inst. 2007, 99, 628-638. [CrossRef] [PubMed]

102. Nagy, P.; Friedländer, E.; Tanner, M.; Kapanen, A.I.; Carraway, K.L.; Isola, J.; Jovin, T.M. Decreased accessibility and lack of activation of ErbB2 in JIMT-1, a herceptin-resistant, MUC4-expressing breast cancer cell line. Cancer Res. 2005, 65, 473-482. [PubMed]

103. Mitra, D.; Brumlik, M.J.; Okamgba, S.U.; Zhu, Y.; Duplessis, T.T.; Parvani, J.G.; Lesko, S.M.; Brogi, E.; Jones, F.E. An oncogenic isoform of HER2 associated with locally disseminated breast cancer and trastuzumab resistance. Mol. Cancer Ther. 2009, 8, 2152-2162. [CrossRef]

104. Castiglioni, F.; Tagliabue, E.; Campiglio, M.; Pupa, S.M.; Balsari, A.; Ménard, S. Role of exon-16-deleted HER2 in breast carcinomas. Endocr. Relat. Cancer 2006, 13, 221-232. [CrossRef]

105. Turpin, J.; Ling, C.; Crosby, E.J.; Hartman, Z.C.; Simond, A.M.; Chodosh, L.A.; Rennhack, J.P.; Andrechek, E.R.; Ozcelik, J.; Hallett, M.; et al. The ErbB2 $\Delta$ Ex16 splice variant is a major oncogenic driver in breast cancer that promotes a pro-metastatic tumor microenvironment. Oncogene 2016, 35, 6053-6064. [CrossRef]

106. Castagnoli, L.; Iezzi, M.; Ghedini, G.C.; Ciravolo, V.; Marzano, G.; Lamolinara, A.; Zappasodi, R.; Gasparini, P.; Campiglio, M.; Amici, A.; et al. Activated d16HER2 homodimers and SRC kinase mediate optimal efficacy for trastuzumab. Cancer Res. 2014, 74, 6248-6259. [CrossRef]

107. Castagnoli, L.; Ghedini, G.C.; Koschorke, A.; Triulzi, T.; Dugo, M.; Gasparini, P.; Casalini, P.; Palladini, A.; Iezzi, M.; Lamolinara, A.; et al. Pathobiological implications o.of the d16HER2 splice variant for stemness and aggressiveness of HER2-positive breast cancer. Oncogene 2017, 36, 1721-1732. [CrossRef]

108. Alajati, A.; Sausgruber, N.; Aceto, N.; Duss, S.; Sarret, S.; Voshol, H.; Bonenfant, D.; Bentires-Alj, M. Mammary tumor formation and metastasis evoked by a HER2 splice variant. Cancer Res. 2013, 73, 5320-5327. [CrossRef]

109. Volpi, C.C.; Pietrantonio, F.; Gloghini, A.; Fucà, G.; Giordano, S.; Corso, S.; Pruneri, G.; Antista, M.; Cremolini, C.; Fasano, E.; et al. The landscape of d16HER2 splice variant expression across HER2-positive cancers. Sci. Rep. 2019, 9, 3545. [CrossRef]

110. Castagnoli, L.; Ladomery, M.; Tagliabue, E.; Pupa, S.M. The d16HER2 Splice Variant: A Friend or Foe of HER2-Positive Cancers? Cancers 2019, 11, 902. [CrossRef] [PubMed]

111. Cocco, E.; Lopez, S.; Santin, A.D.; Scaltriti, M. Prevalence and role of HER2 mutations in cancer. Pharm. Ther. 2019, 199, 188-196. [CrossRef]

112. Zuo, W.-J.; Jiang, Y.-Z.; Wang, Y.-J.; Xu, X.-E.; Hu, X.; Liu, G.-Y.; Wu, J.; Di, G.-H.; Yu, K.-D.; Shao, Z.-M. Dual Characteristics of Novel HER2 Kinase Domain Mutations in Response to HER2-Targeted Therapies in Human Breast Cancer. Clin. Cancer Res. 2016, 22, 4859-4869. [CrossRef]

113. Baldassarre, T.; Truesdell, P.; Craig, A.W. Endophilin A2 promotes HER2 internalization and sensitivity to trastuzumab-based therapy in HER2-positive breast cancers. Breast Cancer Res. 2017, 19, 110. [CrossRef]

114. Raja, S.M.; Clubb, R.J.; Bhattacharyya, M.; Dimri, M.; Cheng, H.; Pan, W.; Ortega-Cava, C.; Lakku-Reddi, A.; Naramura, M.; Band, V. A combination of Trastuzumab and 17-AAG induces enhanced ubiquitinylation and lysosomal pathway-dependent ErbB2 degradation and cytotoxicity in ErbB2-overexpressing breast cancer cells. Cancer Biol. Ther. 2008, 7, 1630-1640. [CrossRef]

115. Austin, C.D.; De Mazière, A.M.; Pisacane, P.I.; van Dijk, S.M.; Eigenbrot, C.; Sliwkowski, M.X.; Klumperman, J.; Scheller, R.H. Endocytosis and sorting of ErbB2 and the site of action of cancer therapeutics trastuzumab and geldanamycin. Mol. Biol. Cell 2004, 15, 5268-5282. [CrossRef] [PubMed]

116. Chung, Y.-C.; Kuo, J.-F.; Wei, W.-C.; Chang, K.-J.; Chao, W.-T. Caveolin-1 dependent endocytosis enhances the chemosensitivity of HER-2 positive breast cancer cells to trastuzumab emtansine (T-DM1). PLoS ONE 2015, 10, e0133072. [CrossRef] 
117. Chung, Y.-C.; Chang, C.-M.; Wei, W.-C.; Chang, T.-W.; Chang, K.-J.; Chao, W.-T. Metformin-induced caveolin-1 expression promotes T-DM1 drug efficacy in breast cancer cells. Sci. Rep. 2018, 8, 3930. [CrossRef] [PubMed]

118. Rios-Luci, C.; Garcia-Alonso, S.; Diaz-Rodriguez, E.; Nadal-Serrano, M.; Arribas, J.; Ocana, A.; Pandiella, A. Resistance to the Antibody-Drug Conjugate T-DM1 Is Based in a Reduction in Lysosomal Proteolytic Activity. Cancer Res. 2017, 77, 4639-4651. [CrossRef]

119. Wang, H.; Wang, W.; Xu, Y.; Yang, Y.; Chen, X.; Quan, H.; Lou, L. Aberrant intracellular metabolism of T-DM1 confers TDM1 resistance in human epidermal growth factor receptor 2-positive gastric cancer cells. Cancer Sci. 2017, 108, 1458-1468. [CrossRef] [PubMed]

120. Li, G.; Guo, J.; Shen, B.Q.; Yadav, D.B.; Sliwkowski, M.X.; Crocker, L.M.; Lacap, J.A.; Phillips, G.D.L. Mechanisms of Acquired Resistance to Trastuzumab Emtansine in Breast Cancer Cells. Mol. Cancer Ther. 2018, 17, 1441-1453. [CrossRef]

121. Kinneer, K.; Meekin, J.; Tiberghien, A.C.; Tai, Y.T.; Phipps, S.; Kiefer, C.M.; Rebelatto, M.C.; Dimasi, N.; Moriarty, A.; Papadopoulos, K.P.; et al. SLC46A3 as a Potential Predictive Biomarker for Antibody-Drug Conjugates Bearing Noncleavable Linked Maytansinoid and Pyrrolobenzodiazepine Warheads. Clin. Cancer Res. 2018, 24, 6570-6582. [CrossRef] [PubMed]

122. Hamblett, K.J.; Jacob, A.P.; Gurgel, J.L.; Tometsko, M.E.; Rock, B.M.; Patel, S.K.; Milburn, R.R.; Siu, S.; Ragan, S.P.; Rock, D.A.; et al. SLC46A3 Is Required to Transport Catabolites of Noncleavable Antibody Maytansine Conjugates from the Lysosome to the Cytoplasm. Cancer Res. 2015, 75, 5329-5340. [CrossRef]

123. Sun, Y.L.; Patel, A.; Kumar, P.; Chen, Z.S. Role of ABC transporters in cancer chemotherapy. Chin. J. Cancer 2012, $31,51-57$. [CrossRef] [PubMed]

124. Robey, R.W.; Pluchino, K.M.; Hall, M.D.; Fojo, A.T.; Bates, S.E.; Gottesman, M.M. Revisiting the role of ABC transporters in multidrug-resistant cancer. Nat. Rev. Cancer 2018, 18, 452-464. [CrossRef]

125. Yamazaki, C.M.; Yamaguchi, A.; Anami, Y.; Xiong, W.; Otani, Y.; Lee, J.; Ueno, N.T.; Zhang, N.; An, Z.; Tsuchikama, K. Antibodydrug conjugates with dual payloads for combating breast tumor heterogeneity and drug resistance. Nat. Commun. 2021, 12, 3528. [CrossRef]

126. Le Joncour, V.; Martins, A.; Puhka, M.; Isola, J.; Salmikangas, M.; Laakkonen, P.; Joensuu, H.; Barok, M. A Novel Anti-HER2 Antibody-Drug Conjugate XMT-1522 for HER2-Positive Breast and Gastric Cancers Resistant to Trastuzumab Emtansine. Mol. Cancer Ther. 2019, 18, 1721-1730. [CrossRef] [PubMed]

127. Takegawa, N.; Nonagase, Y.; Yonesaka, K.; Sakai, K.; Maenishi, O.; Ogitani, Y.; Tamura, T.; Nishio, K.; Nakagawa, K.; Tsurutani, J DS-8201a, a new HER2-targeting antibody-drug conjugate incorporating a novel DNA topoisomerase I inhibitor, overcomes HER2-positive gastric cancer T-DM1 resistance. Int. J. Cancer 2017, 141, 1682-1689. [CrossRef]

128. Phillips, G.D.; Fields, C.T.; Li, G.; Dowbenko, D.; Schaefer, G.; Miller, K.; Andre, F.; Burris, H.A., III; Albain, K.S.; Harbeck, N.; et al. Dual targeting of HER2-positive cancer with trastuzumab emtansine and pertuzumab: Critical role for neuregulin blockade in antitumor response to combination therapy. Clin. Cancer Res. 2014, 20, 456-468. [CrossRef]

129. Saatci, Ö.; Borgoni, S.; Akbulut, Ö.; Durmuş, S.; Raza, U.; Eyüpoğlu, E.; Alkan, C.; Akyol, A.; Kütük, Ö.; Wiemann, S. Targeting PLK1 overcomes T-DM1 resistance via CDK1-dependent phosphorylation and inactivation of Bcl-2/xL in HER2-positive breast cancer. Oncogene 2018, 37, 2251-2269. [CrossRef]

130. Nagata, Y.; Lan, K.H.; Zhou, X.; Tan, M.; Esteva, F.J.; Sahin, A.A.; Klos, K.S.; Li, P.; Monia, B.P.; Nguyen, N.T.; et al. PTEN activation contributes to tumor inhibition by trastuzumab, and loss of PTEN predicts trastuzumab resistance in patients. Cancer Cell 2004, 6, 117-127. [CrossRef] [PubMed]

131. Aghazadeh, S.; Yazdanparast, R. Activation of STAT3/HIF-1 $\alpha /$ Hes-1 axis promotes trastuzumab resistance in HER2overexpressing breast cancer cells via down-regulation of PTEN. Biochim. Biophys. Acta Gen. Subj. 2017, 1861, 1970-1980. [CrossRef] [PubMed]

132. Du, C.; Yi, X.; Liu, W.; Han, T.; Liu, Z.; Ding, Z.; Zheng, Z.; Piao, Y.; Yuan, J.; Han, Y.; et al. MTDH mediates trastuzumab resistance in HER2 positive breast cancer by decreasing PTEN expression through an NFkB-dependent pathway. BMC Cancer 2014, 14, 869. [CrossRef] [PubMed]

133. Berns, K.; Horlings, H.M.; Hennessy, B.T.; Madiredjo, M.; Hijmans, E.M.; Beelen, K.; Linn, S.C.; Gonzalez-Angulo, A.M.; StemkeHale, K.; Hauptmann, M.; et al. A functional genetic approach identifies the PI3K pathway as a major determinant of trastuzumab resistance in breast cancer. Cancer Cell 2007, 12, 395-402. [CrossRef]

134. Sauveur, J.; Matera, E.-L.; Chettab, K.; Valet, P.; Guitton, J.; Savina, A.; Dumontet, C. Esophageal cancer cells resistant to T-DM1 display alterations in cell adhesion and the prostaglandin pathway. Oncotarget 2018, 9, 21141. [CrossRef]

135. Wang, L.; Wang, Q.; Gao, M.; Fu, L.; Li, Y.; Quan, H.; Lou, L. STAT3 activation confers trastuzumab-emtansine (T-DM1) resistance in HER 2-positive breast cancer. Cancer Sci. 2018, 109, 3305-3315. [CrossRef]

136. Islam, S.S.; Uddin, M.; Noman, A.S.M.; Akter, H.; Dity, N.J.; Basiruzzman, M.; Uddin, F.; Ahsan, J.; Annoor, S.; Alaiya, A.A.; et al Antibody-drug conjugate T-DM1 treatment for HER2+ breast cancer induces ROR1 and confers resistance through activation of Hippo transcriptional coactivator YAP1. EBioMedicine 2019, 43, 211-224. [CrossRef]

137. Sauveur, J.; Conilh, L.; Beaumel, S.; Chettab, K.; Jordheim, L.P.; Matera, E.L.; Dumontet, C. Characterization of T-DM1-resistant breast cancer cells. Pharm. Res. Perspect. 2020, 8, e00617. [CrossRef] [PubMed]

138. Matsumoto, T.; Jimi, S.; Hara, S.; Takamatsu, Y.; Suzumiya, J.; Tamura, K. Importance of inducible multidrug resistance 1 expression in HL-60 cells resistant to gemtuzumab ozogamicin. Leuk. Lymphoma 2012, 53, 1399-1405. [CrossRef] 
139. Wei, W.; Lin, Y.; Song, Z.; Xiao, W.; Chen, L.; Yin, J.; Zhou, Y.; Barta, S.K.; Petrus, M.; Waldmann, T.A.; et al. A20 and RBX1 Regulate Brentuximab Vedotin Sensitivity in Hodgkin Lymphoma Models. Clin. Cancer Res. 2020, 26, 4093-4106. [CrossRef]

140. Lewis, T.S.; Gordon, K.; Li, F.; Weimann, A.; Bruders, R.; Miyamoto, J.; Chace, D.; Law, C.-L. Abstract 688: Characterization and circumvention of drug resistance mechanisms in SGN-35-resistant HL and ALCL clonal cell lines. Cancer Res. 2014, 74, 688. [CrossRef]

141. Chen, R.; Herrera, A.F.; Hou, J.; Chen, L.; Wu, J.; Guo, Y.; Synold, T.W.; Ngo, V.N.; Puverel, S.; Mei, M.; et al. Inhibition of MDR1 Overcomes Resistance to Brentuximab Vedotin in Hodgkin Lymphoma. Clin. Cancer Res. 2020, 26, 1034-1044. [CrossRef]

142. Chen, R.; Hou, J.; Newman, E.; Kim, Y.; Donohue, C.; Liu, X.; Thomas, S.H.; Forman, S.J.; Kane, S.E. CD30 Downregulation, MMAE Resistance, and MDR1 Upregulation Are All Associated with Resistance to Brentuximab Vedotin. Mol. Cancer Ther. 2015, 14, 1376-1384. [CrossRef]

143. Kartner, N.; Evernden-Porelle, D.; Bradley, G.; Ling, V. Detection of P-glycoprotein in multidrug-resistant cell lines by monoclonal antibodies. Nature 1985, 316, 820-823. [CrossRef] [PubMed]

144. Gottesman, M.M.; Pastan, I.; Ambudkar, S.V. P-glycoprotein and multidrug resistance. Curr. Opin. Genet. Dev. 1996, 6, 610-617. [CrossRef]

145. Kovtun, Y.V.; Audette, C.A.; Mayo, M.F.; Jones, G.E.; Doherty, H.; Maloney, E.K.; Erickson, H.K.; Sun, X.; Wilhelm, S.; $\mathrm{Ab}, \mathrm{O}$.; et al. Antibody-maytansinoid conjugates designed to bypass multidrug resistance. Cancer Res. 2010, 70, 2528-2537. [CrossRef] [PubMed]

146. Gottesman, M.M.; Pastan, I.H. The Role of Multidrug Resistance Efflux Pumps in Cancer: Revisiting a JNCI Publication Exploring Expression of the MDR1 (P-glycoprotein) Gene. J. Natl. Cancer Inst. 2015, 107, djv222. [CrossRef]

147. Tikhomirov, O.; Carpenter, G. Geldanamycin induces ErbB-2 degradation by proteolytic fragmentation. J. Biol. Chem. 2000, 275, 26625-26631. [CrossRef]

148. D’Amico, L.; Menzel, U.; Prummer, M.; Müller, P.; Buchi, M.; Kashyap, A.; Haessler, U.; Yermanos, A.; Gébleux, R.; Briendl, M.; et al. A novel anti-HER2 anthracycline-based antibody-drug conjugate induces adaptive anti-tumor immunity and potentiates PD-1 blockade in breast cancer. J. Immunother. Cancer 2019, 7, 16. [CrossRef]

149. Conilh, L.; Fournet, G.; Fourmaux, E.; Murcia, A.; Matera, E.L.; Joseph, B.; Dumontet, C.; Viricel, W. Exatecan Antibody Drug Conjugates Based on a Hydrophilic Polysarcosine Drug-Linker Platform. Pharmaceuticals 2021, 14, 247. [CrossRef]

150. Robinson, E.; Nunes, J.P.M.; Vassileva, V.; Maruani, A.; Nogueira, J.C.F.; Smith, M.E.B.; Pedley, R.B.; Caddick, S.; Baker, J.R.; Chudasama, V. Pyridazinediones deliver potent, stable, targeted and efficacious antibody-drug conjugates (ADCs) with a controlled loading of 4 drugs per antibody. RSC Adv. 2017, 7, 9073-9077. [CrossRef]

151. Su, Z.; Xiao, D.; Xie, F.; Liu, L.; Wang, Y.; Fan, S.; Zhou, X.; Li, S. Antibody-drug conjugates: Recent advances in linker chemistry. Acta Pharm. Sin. B 2021. [CrossRef]

152. Holbro, T.; Beerli, R.R.; Maurer, F.; Koziczak, M.; Barbas, C.F.; Hynes, N.E. The ErbB2/ErbB3 heterodimer functions as an oncogenic unit: ErbB2 requires ErbB3 to drive breast tumor cell proliferation. Proc. Natl. Acad. Sci. USA 2003, 100, 8933-8938. [CrossRef] [PubMed]

153. Stern, D.F. ERBB3/HER3 and ERBB2/HER2 duet in mammary development and breast cancer. J. Mammary Gland. Biol. Neoplasia 2008, 13, 215. [CrossRef] [PubMed]

154. McIntyre, E.; Blackburn, E.; Brown, P.J.; Johnson, C.G.; Gullick, W.J. The complete family of epidermal growth factor receptors and their ligands are co-ordinately expressed in breast cancer. Breast Cancer Res. Treat. 2010, 122, 105-110. [CrossRef] [PubMed]

155. Bieche, I.; Onody, P.; Tozlu, S.; Driouch, K.; Vidaud, M.; Lidereau, R. Prognostic value of ERBB family mRNA expression in breast carcinomas. Int. J. Cancer 2003, 106, 758-765. [CrossRef]

156. Capone, E.; Lamolinara, A.; D’Agostino, D.; Rossi, C.; De Laurenzi, V.; Iezzi, M.; Iacobelli, S.; Sala, G. EV20-mediated delivery of cytotoxic auristatin MMAF exhibits potent therapeutic efficacy in cutaneous melanoma. J. Control. Release 2018, 277, 48-56. [CrossRef] [PubMed]

157. Gandullo-Sánchez, L.; Capone, E.; Ocana, A.; Iacobelli, S.; Sala, G.; Pandiella, A. HER3 targeting with an antibody-drug conjugate bypasses resistance to anti-HER2 therapies. EMBO Mol. Med. 2020, 12, e11498. [CrossRef]

158. Geuijen, C.A.; De Nardis, C.; Maussang, D.; Rovers, E.; Gallenne, T.; Hendriks, L.J.; Visser, T.; Nijhuis, R.; Logtenberg, T.; de Kruif, J. Unbiased combinatorial screening identifies a bispecific IgG1 that potently inhibits HER3 signaling via HER2-guided ligand blockade. Cancer Cell 2018, 33, 922-936.e10. [CrossRef]

159. Schram, A.M.; O’Reilly, E.M.; Somwar, R.; Benayed, R.; Shameem, S.; Chauhan, T.; Torrisi, J.; Ford, J.; Maussang, D.; Wasserman, E.; et al. Abstract PR02: Clinical proof of concept for MCLA-128, a bispecific HER2/3 antibody therapy, in NRG1 fusion-positive cancers. In Proceedings of the AACR-NCI-EORTC International Conference on Molecular Targets and Cancer Therapeutics, Boston, MA, USA, 26-30 October 2019. [CrossRef]

160. Jacobsen, H.J.; Poulsen, T.T.; Dahlman, A.; Kjær, I.; Koefoed, K.; Sen, J.W.; Weilguny, D.; Bjerregaard, B.; Andersen, C.R.; Horak, I.D.; et al. Pan-HER, an Antibody Mixture Simultaneously Targeting EGFR, HER2, and HER3, Effectively Overcomes Tumor Heterogeneity and Plasticity. Clin. Cancer Res. 2015, 21, 4110-4122. [CrossRef]

161. Iida, M.; Bahrar, H.; Brand, T.M.; Pearson, H.E.; Coan, J.P.; Orbuch, R.A.; Flanigan, B.G.; Swick, A.D.; Prabakaran, P.J.; Lantto, J.; et al. Targeting the HER Family with Pan-HER Effectively Overcomes Resistance to Cetuximab. Mol. Cancer Ther. 2016, 15, 2175-2186. [CrossRef] 
162. Irie, H.; Kawabata, R.; Fujioka, Y.; Nakagawa, F.; Itadani, H.; Nagase, H.; Ito, K.; Uchida, J.; Ohkubo, S.; Matsuo, K. Acquired resistance to trastuzumab/pertuzumab or to T-DM1 in vivo can be overcome by HER2 kinase inhibition with TAS0728. Cancer Sci. 2020, 111, 2123-2131. [CrossRef]

163. Canonici, A.; Gijsen, M.; Mullooly, M.; Bennett, R.; Bouguern, N.; Pedersen, K.; O’Brien, N.A.; Roxanis, I.; Li, J.L.; Bridge, E.; et al. Neratinib overcomes trastuzumab resistance in HER2 amplified breast cancer. Oncotarget 2013, 4, 1592-1605. [CrossRef] [PubMed]

164. Rabindran, S.K.; Discafani, C.M.; Rosfjord, E.C.; Baxter, M.; Floyd, M.B.; Golas, J.; Hallett, W.A.; Johnson, B.D.; Nilakantan, R.; Overbeek, E.; et al. Antitumor activity of HKI-272, an orally active, irreversible inhibitor of the HER-2 tyrosine kinase. Cancer Res. 2004, 64, 3958-3965. [CrossRef]

165. Wissner, A.; Mansour, T.S. The development of HKI-272 and related compounds for the treatment of cancer. Arch. Pharm. 2008, 341, 465-477. [CrossRef] [PubMed]

166. Li, B.T.; Michelini, F.; Misale, S.; Cocco, E.; Baldino, L.; Cai, Y.; Shifman, S.; Tu, H.Y.; Myers, M.L.; Xu, C.; et al. HER2-Mediated Internalization of Cytotoxic Agents in ERBB2 Amplified or Mutant Lung Cancers. Cancer Discov. 2020, 10, 674-687. [CrossRef]

167. Abraham, J.; Montero, A.J.; Jankowitz, R.C.; Salkeni, M.A.; Beumer, J.H.; Kiesel, B.F.; Piette, F.; Adamson, L.M.; Nagy, R.J.; Lanman, R.B.; et al. Safety and Efficacy of T-DM1 Plus Neratinib in Patients With Metastatic HER2-Positive Breast Cancer: NSABP Foundation Trial FB-10. J. Clin. Oncol. 2019, 37, 2601-2609. [CrossRef]

168. Müller, P.; Kreuzaler, M.; Khan, T.; Thommen, D.S.; Martin, K.; Glatz, K.; Savic, S.; Harbeck, N.; Nitz, U.; Gluz, O.; et al Trastuzumab emtansine (T-DM1) renders HER2+ breast cancer highly susceptible to CTLA-4/PD-1 blockade. Sci. Transl. Med. 2015, 7, 315ra188. [CrossRef] [PubMed]

169. Kepp, O.; Zitvogel, L.; Kroemer, G. Clinical evidence that immunogenic cell death sensitizes to PD-1/PD-L1 blockade Oncoimmunology 2019, 8, e1637188. [CrossRef]

170. Haratani, K.; Yonesaka, K.; Takamura, S.; Maenishi, O.; Kato, R.; Takegawa, N.; Kawakami, H.; Tanaka, K.; Hayashi, H.; Takeda, M. U3-1402 sensitizes HER3-expressing tumors to PD-1 blockade by immune activation. J. Clin. Investig. 2020, 130, 374-388. [CrossRef]

171. Emens, L.; Esteva, F.; Beresford, M.; Saura, C.; De Laurentiis, M.; Kim, S.-B.; Im, S.-A.; Patre, M.; Wang, Y.; Mani, A.; et al. Abstract PD3-01: Results from KATE2, a randomized phase 2 study of atezolizumab (atezo)+trastuzumab emtansine (T-DM1) vs placebo (pbo)+T-DM1 in previously treated HER2+ advanced breast cancer (BC). Cancer Res. 2019, 79, PD3-01. [CrossRef]

172. Waks, A.G.; Keenan, T.; Li, T.; Tayob, N.; Wulf, G.M.; Richardson, E.T.; Mittendorf, E.A.; Overmoyer, B.; Krop, I.E.; Winer, E.P.; et al. A phase Ib study of pembrolizumab (pembro) plus trastuzumab emtansine (T-DM1) for metastatic HER2+ breast cancer (MBC). J. Clin. Oncol. 2020, 38, 1046. [CrossRef]

173. Zoeller, J.J.; Vagodny, A.; Taneja, K.; Tan, B.Y.; O’Brien, N.; Slamon, D.J.; Sampath, D.; Leverson, J.D.; Bronson, R.T.; Dillon, D.A.; et al. Neutralization of BCL-2/X(L) Enhances the Cytotoxicity of T-DM1 In Vivo. Mol. Cancer Ther. 2019, 18, 1115-1126. [CrossRef] [PubMed] 